\title{
Sustaining Environmental Capital Initiative Summary Report
}

Open-File Report 2019-1117 



\title{
Sustaining Environmental Capital Initiative Summary Report
}

By Christopher Huber, James R. Meldrum, Rudy M. Schuster, Zachary H. Ancona, Kenneth J. Bagstad, Scott M. Beck, Daren M. Carlisle, Peter R. Claggett, Fabiano Franco, Heather S. Galbraith, Michelle Haefele, Kristin R. Hoelting, Dianna M. Hogan, Kristina G. Hopkins, Tim Kern, Collin B. Lawrence, Stacy Lischka, John B. Loomis, Julie M. Mueller, Gregory B. Noe, Emily J. Pindilli, Brian Quay, Darius J. Semmens, Wilson Sinclair, Daniel E. Spooner, Brian Voigt, and Barbara St. John White

Open-File Report 2019-1117

\author{
U.S. Department of the Interior \\ U.S. Geological Survey
}




\title{
U.S. Department of the Interior DAVID BERNHARDT, Secretary
}

\author{
U.S. Geological Survey \\ James F. Reilly II, Director
}

\section{U.S. Geological Survey, Reston, Virginia: 2020}

For more information on the USGS - the Federal source for science about the Earth, its natural and living resources, natural hazards, and the environment-visit https://www.usgs.gov or call 1-888-ASK-USGS.

For an overview of USGS information products, including maps, imagery, and publications, visit https://store.usgs.gov.

Any use of trade, firm, or product names is for descriptive purposes only and does not imply endorsement by the U.S. Government.

Although this information product, for the most part, is in the public domain, it also may contain copyrighted materials as noted in the text. Permission to reproduce copyrighted items must be secured from the copyright owner.

Suggested citation:

Huber, C., Meldrum, J.R., Schuster, R.M., Ancona, Z.H., Bagstad, K.J., Beck, S.M., Carlisle, D.M., Claggett, P.R., Franco, F., Galbraith, H.S., Haefele, M., Hoelting, K.R., Hogan, D.M., Hopkins, K.G., Kern, T., Lawrence, C.B., Lischka, S., Loomis, J.B., Mueller, J.M., Noe, G.B., Pindilli, E.J., Quay, B., Semmens, D.J., Sinclair, W., Spooner, D.E., Voigt, B., and St. John White, B., 2020, Sustaining Environmental Capital Initiative summary report: U.S. Geological Survey Open-File Report 2019-1117, 23 p., https://doi.org/10.3133/ofr20191117. 


\section{Acknowledgments}

The Sustaining Environmental Capital Initiative was funded by the Environments Program in the U.S. Geological Survey (USGS) Ecosystems Mission Area. This project has benefited greatly from the help and feedback from colleagues both inside and outside of the USGS, including Carl Shapiro (USGS Science and Decisions Center); Tom Holmes (U.S. Forest Service Southern Research Station); Lydia Olander (Duke University); Randy Rosenberger (Oregon State University); Gail Montgomery (USGS Fort Collins Science Center); Megan Eberhardt Frank and Stephanie Belarde (contractors to the US Fish and Wildlife Service); Erica Patterson (Colorado State University and contractor to the USGS); Ann Miller, Christian Crowley, and Ben Simon (all with the U.S. Department of the Interior's Office of Policy Analysis); and Adam Stern (American Wind Energy Association). The authors would like to expressly thank Frank Casey and Lucas Bair, both with the USGS, for providing critical reviews of this report. 


\section{Contents}

Acknowledgments .......................................................................................................................ii

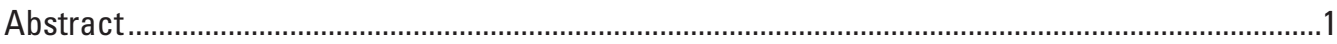

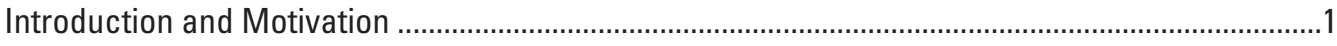

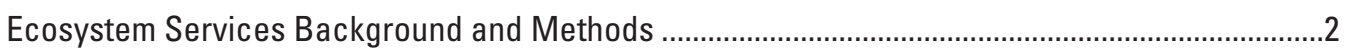

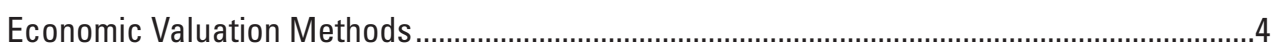

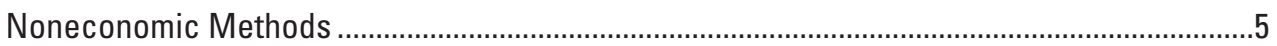

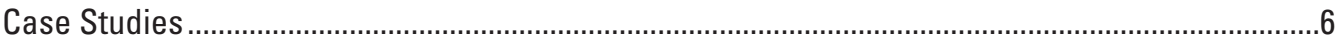

Quantifying and Valuing Floodplain Ecosystem Services in the Chesapeake Bay

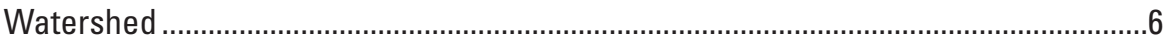

Water Quality and Freshwater Mussels in the Delaware and Susquehanna River Basins—Lessons Learned..........................................................................................7

Mixing National Water Quality Assessment Indicators with Economic House Pricing

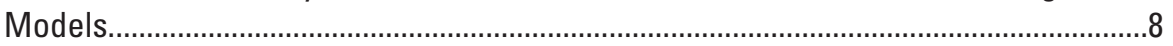

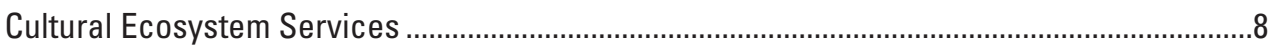

Wilderness Water with the Wilderness Economics Working Group ........................................9

Energy Exploration and Development in the Desert Southwest................................................

Ecosystem Services of Grasslands, Drylands, and Sagebrush Systems ................................10

Forest and Watershed Health in Northern New Mexico …................................................10

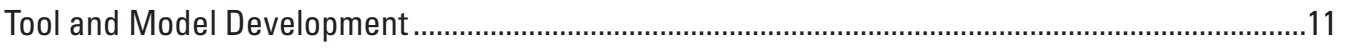

Natural Value Resource Center..............................................................................................11

U.S. Geological Survey Benefit Transfer Toolkit.................................................................12

Process for Integrating Ecosystem Services into the Riverine Environmental Flow Decision Support System....................................................................................12

Artificial Intelligence for Ecosystem Services Modeling Platform-New Developments and an Application in the Desert Southwest .......................................14

Ongoing Activities, Future Research Needs, and Organizational Structure ...................................14

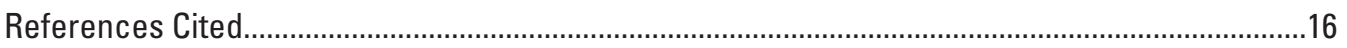

Appendix 1. Sustaining Environmental Capital Initiative Research Products................................21

\section{Figure}

1. Timeline of case studies, tool and model development, and project coordination .3

\section{Table}

1.1. List of Sustaining Environmental Capital Initiative research products 


\section{Conversion Factors}

International System of Units to U.S. customary units

\begin{tabular}{|c|c|c|}
\hline Multiply & By & To obtain \\
\hline \multicolumn{3}{|c|}{ Area } \\
\hline hectare (ha) & 2.471 & acre \\
\hline hectare (ha) & 0.003861 & square mile $\left(\mathrm{mi}^{2}\right)$ \\
\hline \multicolumn{3}{|c|}{ Volume } \\
\hline cubic meter $\left(\mathrm{m}^{3}\right)$ & 264.2 & gallon (gal) \\
\hline \multicolumn{3}{|c|}{ Mass } \\
\hline kilogram (kg) & 2.205 & pound avoirdupois (lb) \\
\hline
\end{tabular}

\section{Abbreviations}

ARIES Artificial Intelligence for Ecosystem Services

BLM Bureau of Land Management

CES Cultural Ecosystem Services

DOI U.S. Department of the Interior

lidar light detection and ranging

NAWQA National Water Quality Assessment

NVRC Natural Value Resource Center

PPGIS Public Participatory Geospatial Information Systems

REFDSS Riverine Environmental Flow Decision Support System

RGWF Rio Grande Water Fund

RSQA Regional Stream Quality Assessment

SECI Sustaining Environmental Capital Initiative

USGS U.S. Geological Survey 



\title{
Sustaining Environmental Capital Initiative Summary Report
}

\author{
By Christopher Huber, James R. Meldrum, ${ }^{1}$ Rudy M. Schuster, ${ }^{1}$ Zachary H. Ancona, ${ }^{1}$ Kenneth J. Bagstad, ${ }^{1}$ \\ Scott M. Beck, ${ }^{2}$ Daren M. Carlisle, ${ }^{1}$ Peter R. Claggett, ${ }^{1}$ Fabiano Franco, ${ }^{3}$ Heather S. Galbraith, ${ }^{1}$ Michelle \\ Haefele, ${ }^{4}$ Kristin R. Hoelting, ${ }^{4}$ Dianna M. Hogan, ${ }^{1}$ Kristina G. Hopkins, ${ }^{1}$ Tim Kern, ${ }^{1}$ Collin B. Lawrence, ${ }^{1}$ \\ Stacy Lischka, ${ }^{2}$ John B. Loomis, ${ }^{4}$ Julie M. Mueller, ${ }^{5}$ Gregory B. Noe, ${ }^{1}$ Emily J. Pindilli, ${ }^{1}$ Brian Quay, ${ }^{6}$ \\ Darius J. Semmens, ${ }^{1}$ Wilson Sinclair, ${ }^{2}$ Daniel E. Spooner, ${ }^{7}$ Brian Voigt, ${ }^{8}$ and Barbara St. John White ${ }^{1}$
}

\begin{abstract}
Federal agencies need credible scientific information to determine the production and value of ecosystem services in an efficient and timely manner. The U.S. Geological Survey addresses this scientific information need through the Sustaining Environmental Capital Initiative project. The project has relied on U.S. Geological Survey expertise related to water, fisheries, advanced modeling, and economics and other social sciences to conduct eight case studies across a range of environment types, including water-based environments, deserts, sagebrush ecosystems, floodplains, and forests. The Sustaining Environmental Capital Initiative also supported the development and expansion of four tools with the intent of adding content and usability for partners' decision-making needs. The tools are the Natural Value Resource Center, Benefit Transfer Toolkit, Riverine Environmental Flow Decision Support System, and Artificial Intelligence for Ecosystem Services modeling platform.
\end{abstract}

\section{Introduction and Motivation}

This report summarizes the activities and progress of the U.S. Geological Survey (USGS) Sustaining Environmental Capital Initiative (SECI) project since its inception in 2015. The grand vision of the SECI is to utilize USGS expertise in various scientific disciplines within the context of the cross-cutting, transdisciplinary field of ecosystem services. The SECI was motivated by the President's Council of Advisors on Science and Technology report "Sustaining Environmental Capital: Protecting Society and the Economy." The report states that "Federal agencies with responsibilities relating to ecosystems and their services [are] tasked with improving their capabilities to develop valuations for the ecosystem services affected by their decision making and factoring the results into analyses that inform their major planning and management decisions" (President's Council of Advisors on Science and Technology, 2011, p. iii). In addition, the memorandum M-16-01 "Incorporating Ecosystem Services into Federal Decision Making," from the Office of Management and Budget, the Council on Environmental Quality, and the Office of Science and Technology Policy, directs Federal agencies to institute policies that consider ecosystem services in planning, investments, and regulatory contexts, where appropriate (Office of Management and Budget, Council on Environmental Quality, and Office of Science and Technology Policy, 2015).

\footnotetext{
${ }^{1}$ U.S. Geological Survey.

${ }^{2}$ Fort Collins, Colorado; work done under contract to U.S. Geological Survey.

${ }^{3}$ U.S. Department of the Interior's Office of Policy Analysis.

${ }^{4}$ Colorado State University.

${ }^{5}$ Northern Arizona University.

${ }^{6}$ Centers for Disease Control and Prevention.

${ }^{7}$ Lock Haven University.

${ }^{8}$ University of Vermont.
} 
Because of this motivating guidance, Federal agencies need credible scientific tools that assist in determining the identification, production, and valuation of ecosystem services in an efficient and timely manner. The USGS has provided scientific support to meet this goal through the SECI and by leveraging USGS expertise and national programs related to water, fisheries, advanced modeling, and economics and other social sciences. There are two broad objectives for the SECI. The first is to provide guidance for using scientific information on ecosystem services in management decisions. The second is to develop, integrate, and enhance natural resource management decision support tools to better enable managers to account for the benefits people receive from ecosystem services. To achieve both objectives, a series of case studies was designed to demonstrate best scientific practices for considering ecosystem services across a range of environment types (water, forests, drylands, and grasslands). The SECI also supported the development and expansion of four tools with the intent of adding content and usability for partners' decision-making needs.

Research has classified at least 342 specific and measurable ecosystem services (Landers and Nahlik, 2013), many of which are difficult to quantify in biophysical terms and (or) value with economic tools. In addition to the number of potential ecosystem services, the number of contexts where ecosystem services are produced on U.S. Department of the Interior (DOI) lands and waters makes it nearly impossible to create an exhaustive resource of example applications. The vision for selecting SECI case studies was to identify those that would represent a variety of (1) ecosystem services, (2) ecological contexts, (3) economic and noneconomic valuation methods, (4) DOI relevant decision-making contexts, and (5) information application processes. Most importantly, each case study addressed an on-the-ground decision-making need and answered management relevant questions.

By reviewing the SECI case studies, DOI resource managers may find results that can be directly transferred to address their needs, a study that can be replicated, or guidance on designing a new project to address a unique need. The DOI Natural Resource Value Center (https://doi.sciencebase.gov/nvrc/\#/) was designed to house SECI case study information and help DOI managers find SECI resources to fulfill their ecosystem service information needs. Working toward this vision, the SECI consists of more than 40 collaborating scientists working on 12 different research case studies and ecosystem service tools. The SECI was designed to last 3 fiscal years, from 2015 through 2017, but some of the case studies and tool-development projects supported by the SECI have lasted longer. A timeline of the case studies, tool and model development, and project management is provided in figure 1.

\section{Ecosystem Services Background and Methods}

In many ways, the concept of ecosystem services is not new. Although the term "ecosystem services" is a relatively recent construction (commonly attributed to Ehrlich and Ehrlich, 1981), the underlying concept that nature provides benefits to people has been around for many years. In fact, the concept of ecosystem services arguably can be interpreted from the 1879 Organic Act (20 Stat. 394; 43 U.S.C. 31) that established the USGS (Shapiro, 2015). The Act provided for "the classification of the public lands and examination of the geological structure, mineral resources, and products of the national domain" [emphasis added]. Indeed, economists have long evaluated the value of goods provided by natural processes that are harvested or otherwise developed by people for use, such as timber and crops (for example, Hotelling, 1931). More specifically in the Federal context, the need to understand the economic implications of water infrastructure projects throughout the American West has been cited as a major motivation for developing methods to quantity the benefits and costs of publicly funded projects. (Banzhaf [2010] provides a historical perspective.) Specific legislation addressing water project investments includes the Reclamation Act of 1902 (Pub.L. 57-161) and the Flood Control Act of 1936 (Pub.L. 74-738). Formal guidance on cost-benefit analyses for water projects was first outlined by the Federal Inter-Agency River Basin Committee (1950). Since 1981, the Federal government has been instructed to assess the costs and benefits of major spending projects as directed by Executive Order 12291—Federal Regulation. Other relevant legislation addressing costs and benefits from Federal projects include the Clean Water Act (33 U.S.C. $\S 1251$ et seq. [1972]); Comprehensive Environmental Response, Cleanup and Liability Act (42 U.S.C. $\$ 9601$ et seq. [1980]); and Oil Pollution Act (33 U.S.C. §2701 et seq. [1990]).

Considerable attention, especially after World War II, focused on the need for and challenges associated with measuring the economic benefits of outdoor recreation because Americans were spending increasingly more of their leisure time in the outdoors (Banzhaf, 2010; Richardson and Peacock, 2018). In response to this need, the travel cost model to measure the economic benefits of outdoor recreation was first conceived by Herold Hotelling in the 1940s (National Park Service, 1949) and then was applied (Trice and Wood, 1958) and later refined (Knetsch and Davis, 1966) by the early 1960s. In addition, contingent valuation, which is a type of stated preference method, was first applied around this time (Davis, 1963). Combined, these recreationfocused analytical approaches contributed to the development of the environmental economics practice of nonmarket valuation, which is a critical component of rigorous and inclusive cost-benefit analysis.

Concurrent with this increased focus by economists on recreation was the recognition of a broader set of ways that society potentially benefits from the natural environment and the relevance of these benefits to decision making. For example, although principally concerned with negative externalities such as pollution, the seminal environmental economics article 


\begin{tabular}{|c|c|c|c|c|c|}
\hline & 2015 & 2016 & 2017 & 2018 & 2019 \\
\hline \multicolumn{6}{|l|}{ Project management-FCSC (3) } \\
\hline \multicolumn{6}{|l|}{ Case studies } \\
\hline \multicolumn{6}{|l|}{ Quantifying and Valuing Floodplain Ecosystem Services in the Chesapeake Bay Watershed_EGSC (1), SAWSC (1), SDC (3), WVU (1) } \\
\hline \multicolumn{6}{|l|}{ Water Quality and Freshwater Mussels in the Delaware and Susquehanna River Basins—Lessons Learned—CSU (2), FCSC (2), LSC (3) } \\
\hline \multicolumn{6}{|l|}{ Mixing National Water Quality Assessment Indic ators with Economic House Price Models—FCSC (3), NAWQA (1) } \\
\hline \multicolumn{6}{|l|}{ Cultural Ecosystem Services—CSU (1), FCSC (1) } \\
\hline \multicolumn{6}{|l|}{ Wilderness Water with the Wilderness Economics Working Group_FCSC (2) } \\
\hline \multicolumn{6}{|l|}{ Energy Exploration and Development in the Desert Southwest-FCSC (3) } \\
\hline \multicolumn{6}{|l|}{ Ecosystem Services of Grasslands, Drylands, and Sagebrush Systems—CSU (2), FCSC (2) } \\
\hline \multicolumn{6}{|l|}{ Forest and Watershed Health in Northern New Mexico-FCSC (2), NAU (1) } \\
\hline \multicolumn{6}{|l|}{ Tool and model development } \\
\hline \multicolumn{6}{|l|}{ Natural Value Resource Center-FCSC (7), PPA (3) } \\
\hline \multicolumn{6}{|l|}{ U.S. Geological Survey Benefit Transfer Toolkit—FCSC (4) } \\
\hline \multicolumn{6}{|l|}{ Process for Integrating Ecosystem Services into the Riverine Environmental Flow Decision Support System—CSU (2), FCSC (1), GEC (3), LSC (3) } \\
\hline Artificial Intelligence for Ecosystem Services Modeling Platform: New Developments and an Application the Desert Southwest-FCSC (2), UVM (1) & & & & & \\
\hline
\end{tabular}

Figure 1. Timeline of case studies, tool and model development, and project coordination. The figure shows the number of participating scientists (in parenthesis) from each organization. (CSU, Colorado State University; EGSC, Eastern Geographic Science Center; FCSC, Fort Collins Science Center; GEC, Geosciences and Environmental Change Science Center; LSC, Northern Appalachian Research Laboratory, Leetown Science Center; NAU, Northern Arizona University; NAWQA, National Water-Quality Assessment Program; PPA, Office of Policy Analysis, U.S. Department of the Interior; SAWSC, South Atlantic Water Science Center; SDC, Science and Decisions Center; UVM, University of Vermont; WVU, West Virginia University) 
Sustaining Environmental Capital Initiative Summary Report

by Coase (1960) also underscored the importance of considering the "total effect" of economic decisions, that is, that all decisions invoke a wide portfolio of opportunity costs that are relevant to a social planner, including the ability of individuals ".. to enjoy a view, to have peace and quiet or to breathe clean air" (p. 44). Krutilla (1967) continued this trend by more thoroughly enumerating and discussing the set of possible uses of the natural, or undeveloped, environment, including those relating to its aesthetic quality, scientific value, and even the concept of "passive use," which refers to the benefits generated merely from considering or knowing the existence of something rather than interacting with it. Shortly thereafter, Freeman and others (1973) put forth a view of the natural environmental consistent with the contemporary concept of ecosystem services:

“... an asset or a kind of nonreproducible capital good that produces a stream of various services for man. Services are tangible (such as flows of water or minerals), or functional (such as the removal, dispersion, storage, and degradation of wastes or residuals), or intangible (such as a scenic view)" (p. 20, as quoted in Freeman [2003], p. 4).

What is perhaps most notable about these developments was their consideration of the use of an intact environment when more conventional economics conceived of the natural environment as principally a source of raw materials of production.

From there, the concept continued to gain steam, albeit slowly at first, as economists started to attach estimates to these broader sets of ecosystem benefits for people. Westman (1977) provided numerous examples of the contributions of ecosystem functions to human welfare and developed estimates of the monetary value of some of these. Perrings and others (1992) urged, and demonstrated possibilities for, closer linkages between economics and ecology to confront the growing challenges of biodiversity loss, including a focus on "the economic valuation of ecological services" (p. 201), and Constanza and Daly (1992) described ecosystems as "renewable natural capital" that yields ecosystem goods as well as "a flow of ecosystem services when left in place" (p. 38). Daily's (1997) book on nature's services helped popularize the concept of the benefits from the environment as "ecosystem services." The Costanza and others (1997) article in the journal Nature brought a great deal of attention to the subject by assessing the total value of the World's ecosystems, opening the floodgates not only for similar analyses conducted at more local scales but also for criticism of the approach used in that article. In particular, many economists, including those who had spent careers working on similar questions in the field of environmental economics, felt trepidation about the meaning and usefulness of the values presented in the Costanza and others (1997) article because of the authors' cavalier treatment of critical economic concepts such as substitutability, income effects, context specificity, and the differences between marginal and total values (for example, Toman, 1998; Bockstael and others, 2000).

Thus, concerted efforts to improve the rigor for categorizing ecosystem services and linking the concept to economic theory were started. In 2005, the Millennium Ecosystem Assessment formalized a categorization of ecosystem services into four general service categories: supporting, provisioning, regulating, and cultural services (Millennium Ecosystem Assessment, 2005). Brown and others (2007) further refined this categorization and placed the concept within an economic framework, emphasizing the distinction between underlying ecosystem processes and the ecosystem goods and services enjoyed by people as well as the role of scarcity in the valuation of them. Similarly, Boyd and Banzhaf (2007) underscore the importance of separating intermediary services from final ecosystem services, which are those that are "directly enjoyed, consumed, or used" (p. 619). In short, understanding and quantifying ecosystem services in a meaningful way involves considering not just one use of the environment in isolation from the others - whether the extractive use of timber, the provision of recreational hiking opportunities, or the lifesustaining processing of carbon dioxide into oxygen - but rather the contribution of the entire system of natural processes to the welfare of people.

\section{Economic Valuation Methods}

One important consideration in public decision making is economic efficiency, which provides a useful framework for evaluating the effects of changes in ecosystem services. Economic efficiency addresses two important issues: (1) maximizing net economic benefits when facing scarcity and competing uses; and (2) providing a way to evaluate the opportunity costs, or forgone benefits, of competing projects or objectives (Young and Loomis, 2014). Economic theory considers the "benefits" or "value" of an outcome relative to the tradeoffs that individuals are willing to make among alternatives (Segerson, 2017), and deems that the important policy-relevant case is at the incremental (or marginal) change in an ecosystem service (Hanemann, 2005; U.S. Environmental Protection Agency, 2013). As such, the economically efficient outcome of resource allocation decisions occurs when marginal benefits are equal across all uses (Gibbons, 1986).

The appropriate method to use to measure the economic value of an ecosystem service depends greatly on the resource context and use. In some cases, the value may be revealed by existing markets. For example, for municipal water uses, it is possible to estimate demand curves and variations in rates of consumption due to changes in price or quantity supplied (that is, elasticities). (See Espey and others [1997] and Dalhuisen and others [2001] for summaries.) For agricultural water use, estimating the marginal value of water includes using water-crop production functions and farm crop budget analyses. (See Scheierling and others [2006] for a review of price elasticities of irrigation water demand.) The marginal value of water for industrial purposes can be calculated as inputs to production (Young and Loomis, 2014). However, many instream water uses are characterized as 
being nonconsumptive and nonexcludable, and are therefore considered public goods that are not traded in markets and thus do not have observable prices. Nonexcludability refers to one's lack of ability to technically and cost-effectively restrict others from using a resource (Young and Loomis, 2014). Consequently, nonmarket valuation techniques are relied upon to elicit associated values for many ecosystem services that are considered public goods (Champ and others, 2017). Because many ecosystem services are public goods without a formal market, estimating marginal tradeoffs in dollars can be especially useful and important (Habb and McConnell, 2002). Although the economic value of some ecosystem services can be observed in market transactions (for example, use of land for cattle grazing, timber sales), the focus of SECI research is on those ecosystem services that can be considered nonmarket in character.

Nonmarket valuation methods can be generally grouped into two broad categories: revealed preference methods and stated preference methods (Champ and others, 2017). The basic approach to revealed preference methods includes estimating value from observed behaviors and expenditures in related markets. These techniques infer value from observed data, such as trip costs, residential property values, and reported averting behaviors, and can be applied to public goods that are used by consumers (for example, outdoor recreation, aesthetics, and responses to poor air quality). SECI research that fits into the revealed preference category includes the National Water Quality Assessment (NAWQA) water quality study that relies on the hedonic property premium approach (see the "Mixing National Water Quality Assessment Indicators with Economic House Pricing Models" section). The hedonic method uses recorded housing sale prices within a market to infer people's willingness to pay for an environmental amenity (Taylor, 2017).

In contrast, stated preference methods use surveys to ask people their value based on a hypothetical change to a good or service. Stated preference techniques include the contingent valuation method (Boyle, 2017) and choice models (conjoint or choice experiments) (Holmes and others, 2017), both of which are flexible enough to accommodate both use values (for example, mountain biking, angling) and nonuse (or passive use) values. An example of a nonuse value is the enjoyment a person receives from knowing that a resource exists for its own sake (existence values) or for future generations (bequest values) regardless of their actual use of or interaction with the resource (Krutilla, 1967; Freeman, 2003). Stated preference techniques are the only methods available to measure the magnitude of these nonuse values, and essentially ask for people's willingness to pay to preserve a resource regardless of actual use. (See Richardson and Loomis [2009] for a summary of people's willingness to pay to preserve rare, threatened, and endangered species in the United States.) SECI research that fits into the stated preference category includes the use of the contingent valuation method for water quality improvements in the Susquehanna River Basin (see the "Water Quality and Freshwater Mussels in the Delaware and Susquehanna River Basins-Lessons Learned" section); the choice experiment for the grasslands, drylands, sagebrush study (see the "Ecosystem Services of Grasslands, Drylands, and Sagebrush Systems" section); and the choice experiment for forest and watershed health study in northern New Mexico study (see the "Forest and Watershed Health in Northern New Mexico" section).

In addition to the stated and revealed preference methods for evaluating nonmarket values, there are cost-based methods that can be used to estimate the value of ecosystem services when certain requirements are met to ensure valid estimation (Brown, 2017). SECI research that uses cost-based approaches includes the replacement cost approach for nutrient and sediment retention and damage costs avoided for flood attenuation in the Chesapeake Bay watershed (see the "Quantifying and Valuing Floodplain Ecosystem Services in the Chesapeake Bay Watershed" section). Cost-based approaches rely on the assumption that if an ecosystem service were to degrade or disappear, a costly technological fix would take its place. For example, the cost of wastewater treatment plants serves as a proxy for the value of retaining nutrients and sediment in natural floodplains.

The final economic method demonstrated in the SECI research portfolio is the benefit transfer method, which relies on the use of existing nonmarket valuation data from a previously conducted study and applies that estimate to a new, unstudied location or context (Johnston and others, 2015; Rosenberger and Loomis, 2017). The benefit transfer method may be the only practical option available to an analyst when budget and time constraints will not allow for a new data collection effort. SECI research supported the USGS Benefit Transfer Toolkit web-application platform (https://my.usgs.gov/benefit-transfer/) to compile existing nonmarket valuation data that public land management agencies can use to conduct benefit transfer analyses (see the "USGS Benefit Transfer Toolkit" section). SECI research demonstrates the application of the benefit transfer method by using existing valuation estimates to calculate the value of water flowing from designated wilderness areas in the United States (see the "Wilderness Water with the Wilderness Economics Working Group" section).

\section{Noneconomic Methods}

In addition to the economic valuation methods used in SECI research, other approaches can be used to determine people's preferences for environmental goods and services. The SECI partnered with Colorado State University (Fort Collins, Colorado) to identify ways to incorporate knowledge from different ontologies and epistemologies, including traditional and local knowledges, into Federal decision making. This qualitative case study (see the "Cultural Ecosystem Services" section) will collect data through interviews using an iterative and participatory methodological approach consistent with practice-based and grounded theory research traditions (Charmaz, 2006; Arts and others, 2013). Key goals of this research include development of a typology 
representing less tangible cultural ecosystem services (CES) knowledge products (that is, sources of knowledge about the cultural importance of the natural World) and an assessment framework to help identify opportunities for improved consideration of a broader range of knowledge products in Federal decision making. For another case study, SECI used the noneconomic method of public participatory geospatial information systems (PPGIS), as described in the "Energy Exploration and Development in the Desert Southwest" section. The aim of that study is to use a mixed-methods framework to collect spatial information useful for generating maps of important ecosystem services for on-the-ground stakeholders in the Colorado Plateau area.

\section{Case Studies}

The eight SECI case studies were selected to demonstrate best practices in the ecosystem services field. Motivations for selecting these case studies were to leverage USGS research strengths and to showcase the use of different methods to place value on a variety of ecosystem services and ecosystem types. The USGS has a strong tradition of studying water quality (for example, the NAWQA program) and quantity (for example, the streamgage network), and thus, it was a natural place to begin. In addition to the water-based ecosystem services studies, the SECI case studies include desert, sagebrush, floodplain, and forest ecosystem types.

\section{Quantifying and Valuing Floodplain Ecosystem Services in the Chesapeake Bay Watershed}

Streams and floodplains provide many ecosystem services to communities, including water quality regulation, wildlife habitat, flood attenuation, and recreational opportunities. Floodplains lie at the intersection of the terrestrial and aquatic environments and provide a dynamic environment with the ability to store floodwaters, accumulate sediments and nutrients through deposition, and export material downstream through erosion. Improving the techniques used to quantify floodplain ecosystem services provides decision makers with valuable information that can be used to prioritize land use, conservation, and restoration decisions. The objective of this case study was to provide ecosystem service information on streams and floodplains that could be used for land-use decision making. Accordingly, the study quantified and valued the capacity of floodplains in the Chesapeake Bay watershed to retain sediment, nutrients, and floodwaters. The case study team developed modeling approaches to scale existing USGS field datasets on floodplain function to the larger stream network using characteristics of the watershed and stream geometry. This integrated approach is scalable and transferable to watersheds outside of the Chesapeake Bay if appropriate datasets are available for validation.

A pilot study in the Difficult Run watershed (Virginia) included analyses to quantify and determine the value of sediment and nutrient retention and flood attenuation services provided by floodplains. This study site was selected because it is within the Chesapeake Bay watershed, there is extensive field data on floodplain nutrient and sediment flux available, and light detection and ranging (lidar) datasets allow for the high-resolution mapping of floodplain physical characteristics. Sediment and nutrient retention services were quantified by developing a model to predict sediment and nutrient flux from the uplands, streambanks, and floodplain for more than 3,000 stream segments in the Difficult Run watershed (Hopkins and others, 2018c).

The USGS Stream Channel and Floodplain Metric Toolbox

(https://www.sciencebase.gov/catalog/item/59fb02d2e4b0531197b1618a) was developed and used to extract floodplain physical characteristics, such as floodplain extent and width, floodplain topography, and channel dimensions for more than 3,000 stream segments in the watershed (Hopkins and others, 2018a). A model was developed to link these physical characteristics and information from the field datasets to predict the net flux of sediment and nutrients (nitrogen and phosphorus) from streambanks and floodplains in the study area (Hopkins and others, 2018b). Economic models were then used to estimate the annual monetary value of sediment and nutrient retention services in the study area (Hopkins and others, 2018c). Flood attenuation services provided by floodplains in the Difficult Run watershed were quantified and the value of the services was determined by combining lidar datasets with the GIS Flood Tool and USGS streamflow records to simulate flooding extent for a baseline and counterfactual scenario and to identify the difference in flood damages with and without floodplain storage (Lawrence and others, 2019). Ecosystem service valuation using a replacement cost approach for nutrient and sediment retention and damage costs avoided for flood attenuation was used. The approaches employed in these studies were specifically designed to provide an adaptable, scalable approach that adds ecosystem service valuation methods at management-ready scales to the SECI framework.

Results of the sediment and nutrient retention study of floodplains in the Difficult Run watershed indicate that, in year 1, there is a net flux of -10.4 million kilograms of sediment (net export), 57,300 kilograms of sediment-bound nitrogen (net trapping), and 98 kilograms of sediment-bound phosphorus (net trapping) (Hopkins and others, 2018c). Nutrient retention in the floodplains exceeded that lost through stream bank erosion resulting in net trapping of nutrients (total nitrogen and total phosphorus) on the floodplain. Using a conservative cost estimate of $\$ 12.69$ per kilogram of nitrogen derived from wastewater treatment costs, the annual estimated annual value for sediment and nutrient retention was $\$ 727,000 \pm \$ 194,000$ for the entire 
floodplain area in the Difficult Run watershed and \$233 $\$$ \$61 per hectare of floodplain (Hopkins and others, 2018c). Results from the flood attenuation study estimated floodplains in the Difficult Run watershed can store more than 6 million cubic meters of water. Comparison of flood damages under baseline (with floodplains) and counterfactual (with "filled-in" floodplains) scenarios indicated that the estimated annual marginal benefit of floodplains was $\$ 73,412$ or $\$ 77$ per hectare of floodplain (Lawrence and others, 2019). When flood attenuation and sediment and nutrient retention services are considered together, floodplains in the Difficult Run watershed provide ecosystem services valued at roughly $\$ 800,000$ annually.

This study demonstrates proof-of-concept methods to value the services that floodplains provide to people. These types of biophysical assessments can aid in local land-use decision making by providing spatially explicit conservation priorities for areas with high ecosystem service values. For example, spatial patterns in bank flux could be used to focus restoration efforts on areas with greater bank erosion rates, and spatial patterns in floodplain flux highlight areas that could be conserved to maintain the valuable ecosystem services provided by floodplains. The research team is currently working to extend and apply the research approaches employed in these pilot studies to the larger Chesapeake Bay watershed and the nearby Delaware River watershed.

\section{Water Quality and Freshwater Mussels in the Delaware and Susquehanna River Basins-Lessons Learned}

This effort is investigating the water quality benefits provided by freshwater mussels in the Delaware River Basin. Native freshwater mussels are filter feeders commonly found in streams, lakes, and rivers throughout North America. Through their filtration activities, mussels capture, transform, and remove materials (for example, sediment and nutrients) that would otherwise be transported to estuaries and coasts. In turn, these activities facilitate the growth and biodiversity of local bacteria and algae, critical components of aquatic food webs, as well as invertebrates and fish, other contributors to healthy aquatic ecosystems.

The aim of the study is to improve knowledge of how freshwater mussels filter and clean water in the ecologically intact Upper Delaware River, with the goal of using that information to conserve the largely healthy Upper Delaware River Basin, as well as guide restoration of degraded systems (that is, the Susquehanna River Basin) where questions may arise on whether to invest in improving freshwater mussel habitat. Broadly, this study has three components: (1) evaluate mussel filtration activities that capture, transform, and remove materials from the Delaware River; (2) quantify the economic value of the ecosystem services supported by freshwater mussels; and (3) develop a predictive model for estimating economic and ecological service benefits and losses associated with projected changes to the Delaware River Basin. The study location includes the Delaware River Basin and the neighboring Susquehanna River Basin. Historically, the two river basins had similar ecological systems and have been used for a variety of purposes including navigation, industrial uses, and drinking water. Today, however, the two systems differ in the quality of water flowing in their respective mainstems. The Susquehanna River has high nitrogen, phosphorus, and sedimentation levels as well as other contamination resulting from historic coal mining in the region. In comparison, the Delaware River, particularly in locations close to the headwaters, has relatively clean water that provides the opportunity to investigate the biophysical and natural processes that support the overall quality of the system.

The first research component evaluates how filtration by the freshwater mussel populations within the Delaware River captures, transforms, and removes materials. The case study includes spatially explicit field surveys to characterize mussel data (for example, abundance, size) and environmental data (for example, depth, flow, temperature) at historical sampling sites that coincide with flow data modeled by the Delaware Riverine Environmental Flow Decision Support System (REFDSS) (see the "Process for Integrating Ecosystem Services into the Riverine Environmental Flow Decision Support System" section). The study also includes literature summaries and laboratory experiments to parameterize biofiltration efficiency under varying flows and suspended sediment regimes, and to link riverflow data to biofiltration and nutrient retention efficiencies for freshwater mussels.

The second research component focuses on estimating the economic benefits of freshwater mussels using a household stated preference valuation survey. A valid counterfactual scenario is required when pursuing this type of public survey. Several hypothetical management scenarios were explored in designing the stated preference questionnaire, including modified flows out of the Cannonsville, Pepacton, and Neversink Reservoirs at the north end of the Delaware River Basin, and changes to nutrient loadings from across the landscape to "simulate" changes in the ability of freshwater mussels to cycle nutrients. These hypothetical scenarios lacked the ability to represent a realistic management alternative in the Delaware River, including direct or indirect effects to freshwater mussels, necessary for designing a stated preference survey. Instead, an economic valuation questionnaire was designed to investigate people's willingness to pay for improving overall water quality in the Susquehanna River Basin as a proxy for the Delaware River system. The aims of this component are to estimate people's willingness to pay for reducing nutrient and sediment loading in the Susquehanna River and conduct a benefit transfer to estimate the value of these services in the Delaware River.

The third research component is to develop a framework to integrate the biophysical (research task 1) and the economic (research task 2) information into the REFDSS, if appropriate, or develop a new user interface (see Maloney and others [2015] 
Sustaining Environmental Capital Initiative Summary Report

for background on model development). This third research task is described in detail in the "Process for Integrating Ecosystem Services into the Riverine Environmental Flow Decision Support System" section. Broadly, the vision was to use the REFDSS as a platform to combine freshwater mussel filtration data that was collected by the USGS Leetown Science Center in West Virginia with the economic valuation data that was collected by the USGS Fort Collins Science Center in Colorado.

This study offers the opportunity to learn about the biophysical processes in a relatively intact watershed and use the economic information from a degraded watershed to consider different aspects of ecosystem services science. However, measuring the value of services in a highly managed system is challenging because of institutional and political issues. Specifically, attempting to construct a realistic, yet hypothetical, scenario for a stated preference survey becomes nearly impossible when institutional water management policy does not allow for a flexible decision space, as is the case with the Delaware River Basin. Although it is possible to estimate the total value of services (not including passive use values) as demonstrated by Kauffman (2016), this value does not reflect the marginal values necessary for decision making, a cost-benefit analysis, or a decision support system that predicts incremental outputs (for example, change in nutrient quantity in a river system).

\section{Mixing National Water Quality Assessment Indicators with Economic House Pricing Models}

In comparison to many ecosystem services, the benefits associated with water quality improvements are well studied. One common approach to estimating the value of water quality benefits is the hedonic pricing model, which determines the influence of a water quality indicator on transaction prices for residential property. However, past studies using this technique have focused on water quality in standing bodies of water (such as lakes or bays) and only on a few key indicators such as water clarity, phosphorous loading, dissolved oxygen, or total suspended solids. Similar benefits associated with the water quality of rivers and streams that course through developed areas are not as well studied. Existing estimates of these benefits typically depend on costly and site-specific survey-based stated preference methods.

This study explored the feasibility of leveraging the USGS NAWQA stream health data from the southeastern Regional Stream Quality Assessment (RSQA) to estimate the economic value of water quality in urban streams in Mecklenburg County, North Carolina using the hedonic price method. The NAWQA Program conducts regional assessments of water quality, habitat stressors, and biological communities, with an overall goal of evaluating the relative importance of factors affecting stream health throughout the region. Sampling takes place at many stream sites in the region to analyze gradients of human disturbance and characterize chemical stressors and physical and biological conditions. Building from these data, a series of models predicts the effects of water and habitat quality on various indicators of stream health hypothesized to contribute to human well-being. The goals of this study were to assess the compatibility of these modeled data with a hedonic pricing approach, to inform the collection and use of water quality monitoring data within the NAWQA Program, and to contribute a novel source of natural resource condition information to the environmental economics literature. This analysis contributes to the broader SECI framework of leveraging existing USGS models, programs, and data in developing information about ecosystem services and the benefits they provide to society.

Ultimately, the case study demonstrates challenges with pairing the modeled RSQA data and residential property transactions using the hedonic pricing model. For example, although the RSQA collects more than 700 different variables associated with stream health, few of these were deemed to be indicative of ecosystem attributes that are readily perceptible to people. Based on previous studies, the hypothesis is that two of the variables (minimum dissolved oxygen and conductance) are aspects of water quality that are potentially perceived and valued by actors in the residential property market. However, the water quality prediction models only explain 40 percent and 52 percent of the variation in observed dissolved oxygen and conductance RSQA data, respectively. Further, the hedonic estimation results are either of negligible significance or counterintuitive (for example, suggesting a negative correlation with minimum dissolved oxygen levels when a positive or insignificant one is expected). In this context of weakly predicted data, coefficients that are significant and robust yet do not conform to hypotheses suggest that the model is estimating an aspect of stream condition that had not been anticipated. The next steps in this study will seek a better understanding of the source of this consistent variation and implications for the nonmarket valuation of the benefits of water quality. Additional next steps under consideration involve pursuing other opportunities to leverage NAWQA data for estimating ecosystem service benefits associated with water quality through "benefit transfer" approaches, and pairing RSQA data or other derived outputs, such as inferred habitat suitability for sport fisheries, with previously established economics benefits estimates.

\section{Cultural Ecosystem Services}

The CES study seeks to improve the use of cultural benefits information in Federal decision making. The research will examine use of CES knowledge, which is knowledge about the cultural importance of the natural World, in decision making. Emphasis will be placed on developing tools for identifying opportunities and constraints for use of CES knowledge in specific Federal decisions. The work will contribute to the SECI effort through the development of tools and methods for improved 
identification of available CES knowledge products that provide information about less tangible cultural benefits. Fieldwork for this case study started during fall 2018 and is anticipated to continue into 2020.

The research will involve review of case studies of past Federal decision processes, using open-ended interviews to identify relevant CES knowledge products and trace the use of those knowledge products through decision making. Data collection will be carried out using an iterative and participatory methodological approach consistent with practice-based and grounded-theory research traditions (Charmaz, 2006; Arts and others, 2013). Both research traditions are conducive to the study of culturally and historically situated knowledge and experiences that underlie the coproduction of CES and associated contextual values and meanings (Tengö and others, 2014), as well as the situated practices that influence how knowledge of these values and meanings are communicated and used in environmental decision making (Arts and others, 2013).

This study seeks to fulfill conceptual, theoretical, and practical objectives. First, the research is expected to improve clarity surrounding concepts of CES knowledge and CES knowledge products, which are representations of CES knowledge that have the potential to be communicated to Federal decision makers. Second, the research will build practice-based theory around opportunities and constraints to representation, transmission, and use of CES knowledge products in specific Federal decisionmaking contexts. Third, findings will be used to develop applied tools to improve use of CES knowledge in Federal decision making. Tools will include a typology of CES knowledge products to help identify sources of CES knowledge related to a given decision context, and a framework to assess constraints and enabling factors for representation, transmission, and use of available CES knowledge products.

\section{Wilderness Water with the Wilderness Economics Working Group}

In 2014, the Aldo Leopold Wilderness Research Institute (University of Montana) established the Wilderness Economics Working Group to facilitate research collaboration among Federal agencies on the economic and social dimensions of current and emerging issues confronting American wilderness areas and to develop better communication with the American public and land managers about this important topic. Wilderness resides at a unique nexus in ecosystem services research. Natural systems in wilderness areas are often highly regarded for their relatively "preserved" state, which likely provides substantial ecosystem service benefits to society. However, many characteristics of wilderness areas present obstacles to estimating the economic benefits associated with either the areas themselves or their management. This study aims to characterize approaches to understanding and estimating the nationwide economic value of the many ecosystem services and benefits associated specifically with freshwater that originates in wilderness areas.

The primary goal of this study is scientific communication; as such, an article by Meldrum and Huber (2019) was printed in a special issue of the Natural Areas Journal. The manuscript explores the relationship between wilderness and water resources from an economic perspective. Spatial analyses that demonstrate strong spatial and hydrological links from wilderness areas to downstream users were conducted. The manuscript discusses coarse estimates of the total economic value of this water flowing from wilderness that could be based on this and related information, drawing from benefit transfer estimates, and focusing attention on the limitations of this approach. The article also discusses preliminary examples of the potential specific effects of alternative management schemes on the localized benefits of water resources.

This case study demonstrates that a substantial proportion of the total water resources in the United States originates in wilderness areas and that, accordingly, there exist many important connections between the water resources that society depends upon and the public lands that society protects as wilderness. However, the study also demonstrates theoretical and practical challenges to the more readily available approaches for estimating the value added to water resources by wilderness areas. The study indicates that rigorous characterization of the economic benefits provided by wilderness through water resources will require more studies using these types of alternative approaches and provides a base for embarking on such studies. Next steps for this study consist primarily of seeing the current manuscript through to publication and conducting a limited amount of associated outreach and presentations as part of the Wilderness Economics Working Group.

\section{Energy Exploration and Development in the Desert Southwest}

Drylands (arid and semiarid ecosystems) play an important role in supporting agricultural production, grazing, and outdoor recreation (for local residents and tourists) in the Western United States. Dryland systems in the West also provide opportunities for conventional energy development and renewable energy production. However, activities that result in landscape alternations, such as energy production, can have disproportionally large effects on dryland ecological systems and the human communities that depend on them.

Although energy exploration and development in the West have been major drivers of economic growth and social change for more than 100 years, recent advances in technologies have led to an increase in energy exploration and production activities. Although some land managers have access to high quality information about public use of these lands, many do not, and what 
is available is often focused on estimating visitation and spending. Consequently, there is a need to understand the impacts of energy exploration and development on these economically important landscapes. This case study seeks to develop methods to quantify noneconomic values of public lands that will allow planners to make informed decisions that balance multiple land uses in the region.

To achieve this objective, a tool will be developed using a mixed-methods approach that combines a PPGIS framework with other social science methods (for example, surveys and focus groups) that can be deployed by managers and researchers both online and in the field. This tool will be designed to collect spatially relevant information about the types and intensities of ecosystem services that stakeholders value throughout the Colorado Plateau. The tool will aid in the planning process by helping land managers (1) create baseline spatial inventories of socially oriented ecosystem service values and visitor activities and (2) assess the substitutability of these ecosystem service values when presented with competing land uses by employing hypothetical scenarios. Ultimately, managers can leverage these data to generate "hot spot" maps to identify substitutable ecosystem service provisioning locations and target energy development leases that maximize multiple land uses while mitigating potential conflicts.

Currently, researchers in the Social and Economic Analysis Branch at the USGS Fort Collins Science Center are working in collaboration with the Bureau of Land Management (BLM) and academic partners to develop and pilot this tool. The research team has taken advantage of several collaborative meetings to finalize a schematic outlining the PPGIS and survey process and identify a select list of potential BLM field office test sites within the Colorado Plateau. Additionally, efforts are underway to begin developing the software application with the expectation that a functional pilot tool will be available for beta testing in 2019.

\section{Ecosystem Services of Grasslands, Drylands, and Sagebrush Systems}

Vast stretches of grasslands, drylands, and sagebrush ecosystems throughout the United States are managed by the Federal government. Of the total U.S. land area managed by the Federal government, 43 percent is considered shrub/scrub and 12 percent is herbaceous (grassland) (USGS, 2014; Homer and others, 2015). The BLM manages vast stretches of drylands, grasslands, and sagebrush across the American West. In fact, 70 percent of BLM-managed lands can be categorized as shrub/scrub, with an additional 11 percent considered herbaceous grassland.

These lands are used for a variety of economic purposes, including energy development and livestock grazing, but they also provide other valuable services to society such as habitat for wildlife, biodiversity and species richness, and outdoor recreational opportunities. However, the ecosystem services supported by grasslands and sagebrush are understudied in the economics literature. USGS is partnering with Colorado State University to review what is known about grassland, dryland, and sagebrush ecosystem services with the goal of designing a new data collection effort aimed at filling any discovered gaps. The method that will be used for data collection is a household survey utilizing a choice experiment to understand public preferences among ecological tradeoffs in sagebrush environments. For this case study, the USGS Wyoming Landscape Conservation Initiative, the USGS Southwest Energy Development program, and agricultural economists at the University of Wyoming have been asked to identify priority ecological endpoints necessary for designing the attributes in the choice experiment. The literature review, preliminary ecological attributes for the choice experiment, and sampling protocol were presented at the Great Plains Grassland Summit, which was held April 2018 in Denver, Colorado (Haefele and others, 2018). Results from this study will assist projects aimed at restoration, fire mitigation, invasive species control, and forage improvements for livestock and wildlife.

\section{Forest and Watershed Health in Northern New Mexico}

North-central New Mexico, including the Middle Rio Grande River, Rio Chama River, and their forested tributaries and headwaters, consists of a patchwork of Indian Reservations, private lands, and public lands, including the Santa Fe National Forest and Bandelier National Monument. The region faces the interrelated challenges of maintaining forest health, addressing large-scale fire risk, and protecting water flows. The Rio Grande Water Fund (RGWF), a public-private partnership with many stakeholders and contributors, focuses on addressing these challenges through a 20 -year program of large-scale forest and watershed restoration treatments. Specifically, the RGWF aims to restore 242,000 hectares within the roughly 680,000 hectares of fire-prone ponderosa pine and mixed conifer forest.

Recent studies that used contingent valuation methods to determine the public's willingness to pay for forest restoration, including in the Santa Fe Fireshed (a portion of the RGWF area), help establish an understanding of the economic benefits from forest restoration, thereby loosely quantifying public support for efforts like the RGWF. However, forest restoration provides a host of benefits, including improvements in water quality, increased recreational opportunities, protection of habitat, and reduced wildfire risk to homes and communities. Different approaches and locations of restoration work can lead to different combinations of these benefits, sometimes requiring tradeoffs among them. This case study builds on previous studies by using a choice 
experiment approach to estimate the benefits of these different attributes of restoration. As is typical in rigorous stated preference valuation research, the choice experiment is being developed with a focus on the nexus of social science and ecosystem services - the intersection of human concerns, interests, and values with the outputs of biophysical processes and how they might be affected by alternative management practices.

This case study is still in active development. Reflecting the goal of contributing concurrently to the applied concerns of decision makers in the RGWF and to the more general body of academic knowledge on the benefits of forest treatments and wildfire risk reduction, progress to date has focused on a review of the academic literature and stakeholder discussions. These efforts have led to a refined understanding of needed details of the study, including attributes of interest, the population with standing from the perspective of local decision makers, and important questions to explore, such as the potential for tradeoffs between personal wildfire risk reduction against the more diffuse benefit of source water protection. Next steps involve finalizing the preliminary choice experiment survey, implementing and analyzing the survey, and preparing results for presentation to stakeholders and publication in the academic literature.

\section{Tool and Model Development}

The SECI supported the development and expansion of four tools designed to provide information for partners' decisionmaking needs and support a range of perspectives and applications with respect to ecosystem services science. The tools are the (1) DOI Natural Value Resource Center (NVRC), (2) USGS Benefit Transfer Toolkit, (3) USGS REFDSS, and (4) Artificial Intelligence for Ecosystem Services (ARIES) modeling platform. The NVRC is a new tool designed by the SECI team to be a one-stop-shop "dashboard" of data, models, and guidance for anyone from land use planners to technical experts who desire to incorporate information on ecosystem services in their decision-making processes. The USGS Benefit Transfer Toolkit provides existing economic valuation data for nonmarket goods and services, and is accessible by DOI bureaus, partners, and other agencies for a range of project plans, damage assessments, and regulatory compliance needs. The Delaware REFDSS represents a model that is relatively narrow in focus and scope (to predict species' habitat availability under various management scenarios) but was not intended as an ecosystem services model during its original development. Thus, the REFDSS represents an extension of an existing USGS integrated assessment model into the science of ecosystem services. In contrast, ARIES is a modeling platform equally capable of facilitating the development of static, look-up table models or complex, dynamic, agent-based models whose primary focus is centered on modeling ecological production functions and the flow of ecosystem services between nature and people. ARIES also supports the inclusion of existing economic valuation estimates like those found in the USGS Benefit Transfer Toolkit. Both the USGS Benefit Transfer Toolkit and ARIES model represent existing tools that can be used in a variety of contexts, geographic locations, and applications.

\section{Natural Value Resource Center}

The NVRC (https://doi.sciencebase.gov/nvrc/\#) is a USGS web-based application that engages partners and the research community with the best available USGS science related to ecosystem services (USGS, 2018). The objective of the NVRC is to serve as the USGS "dashboard" for ecosystem services outreach and communication, and to supply data, tools, and research examples to DOI bureaus and other Federal agencies. Forming a community of practice, targeted users of the NVRC range from research scientists conducting economic valuation studies to field-level planners with limited exposure to ecosystem services. Content management within the NVRC web site showcases the ongoing SECI case studies and tool development described throughout this current report. The back-end architecture is flexible and was designed specifically to make it easy to accommodate new data and content. The intent of the website is to improve the efficiency of natural resource management in two ways: (1) facilitate an improved understanding of the tradeoffs associated with land management decisions; and (2) foster interagency engagement, thereby facilitating the sharing and the transfer of relevant expertise across bureaus.

There are three main content areas to the NVRC. The first describes the eight SECI case studies and four tool developments on the NVRC "Efforts" page. The page provides the best available scientific resources for understanding, valuing, and communicating ecosystem services production and tradeoffs. The second content area, the "NVRC Search," provides resources intended to help other practitioners incorporate ecosystem services into their decision making. This is accomplished through the NVRC search capability, which improves the efficiency of internet searches for ecosystem services websites, data repositories, and online documents by pulling results from a curated set of sources. The NVRC search is generated by a ScienceBase Crawler which is a curated collection of search results from a variety of different web-based resources. Databases searched include those stored in USGS ScienceBase, U.S. Environmental Protection Agency's EnviroAtlas, Duke University's National Ecosystem Services Partnership, EcoServe Models Library, National Ocean Economics Program, and the Natural Capital Project. 
The third main content area in the NVRC, "Tools \& Resources," is a compilation of tools and resources to address ecosystem services. The list is based primarily on the work of the National Ecosystem Service Partnership, an initiative of Duke University's Nicholas Institute for Environmental Policy Solutions (Olander and others, 2017), which represents a significant, collaborative effort of many experts in the field. The tools and resources can be filtered by topic (agency examples; ecological data and models; ecosystem-related risks; guidebooks, frameworks, and decision tools; and social and economic data and models), subtopics (including recreational use of biodiversity, flooding risk, wildfire risk, freshwater supply), and type (data, models, and resource).

In addition to the three main content areas, the NVRC also maintains a "Team Members" page that directs users to experts within their respective ecosystem services disciplines. Each SECI team member has listed their respective title (for example, research economist), location, organization, and contribution to the NVRC and SECI project. The objective of this page is to connect managers and practitioners to USGS scientists and SECI partners to support ecosystem services science and decisionmaking needs.

\section{U.S. Geological Survey Benefit Transfer Toolkit}

Many ecosystem services are defined as nonmarket goods that cannot be fully valued by efficient pricing mechanisms from established markets. Understanding the magnitude of benefits from these ecosystem services can be useful when comparing the economic outcomes of different management scenarios and policies. Measuring the nonmarket value of ecosystem services can be accomplished through an original primary nonmarket valuation study. However, nonmarket valuation studies may be infeasible when time and resources are limited. As an alternative, analysts can rely on the benefit transfer method for ecosystem service valuation. This method applies the findings from primary studies to a new, policy-relevant area (Richardson and others, 2015; Rosenberger and Loomis, 2017). The USGS Benefit Transfer Toolkit (https://my.usgs.gov/benefit-transfer/) is designed to facilitate the benefit transfer method by supplying data, models, and guidance that can be used to convert information from prior studies into tailored value estimates for a related context in a policy-relevant area (USGS, 2017).

The USGS Benefit Transfer Toolkit has three main components: nonmarket valuation databases, statistical forecasting models, and recreation activities map. The backbone of the USGS Benefit Transfer Toolkit is the nonmarket valuation databases. The databases include coded summary information for nonmarket valuation studies on 16 types of outdoor recreational activities; surface water quality improvements; preservation of threatened, endangered, and rare species; and salmon population improvements. These databases build off previous summaries and meta-analyses from Richardson and Loomis (2009), Johnston and Thomassin (2010), Weber (2015), Johnston and others (2016), the Recreation Use Values Database (Oregon State University, 2016), and Rosenberger and others (2017). Toolkit users can employ the data in the databases to perform unit value benefit transfer, either by transferring point or average values, or by conducting a statistical meta-regression analysis with the data. Users interested in investigating outdoor recreational use values in the Toolkit can visit an interactive map that identifies the location of site-specific primary studies across the United States for different recreational types. For recreation databases with enough observations (for example, fishing, hunting, trail use, and wildlife viewing), the Toolkit features ready-to-use metaregression "calculators." Here, users choose their study area's attributes (for example, U.S. region, primary fishing type) and the calculator provides a predicted value estimate based on the full body of data within the Toolkit (Huber and others, 2018).

The USGS Benefit Transfer Toolkit is an evolving and interactive resource that allows land managers and decision makers to obtain benefit estimates for ecosystem services without expending the time or funds necessary to conduct a primary study. Updates and improvements to the Toolkit are ongoing. There are currently six new recreation databases in development, as well as updated estimates and improved meta-regression calculators. The goal for the USGS Benefit Transfer Toolkit is to make it easily accessible for practitioners to use existing nonmarket valuation data for their own analyses. The long-term vision of the Toolkit is to meet the needs of USGS, DOI partners, other Federal agencies, state and local governments, private entities, and collaborators undertaking these types of nonmarket valuation analyses.

\section{Process for Integrating Ecosystem Services into the Riverine Environmental Flow Decision Support System}

Freshwater mussels are a native group of filter feeders that can perform important ecosystem processes in freshwater systems (see the "Water Quality and Freshwater Mussels in the Delaware and Susquehanna River Basins—Lessons Learned" section). This research is investigating the incorporation of mussel filtration as an ecosystem service into the REFDSS developed by the USGS for the Upper Delaware River ecosystem. The REFDSS platform was developed as a desktop application that enables comparison of flow scenarios and environmental attributes (for example, instream flow) on instream habitat for a variety of species including fish and mussels (see Maloney and others [2015] for background on model development). The platform focuses 
on 11 sites within the Upper Delaware River Basin. The sites were selected by model developers based on homogeneous flow regime, temperature classifications, and resource issues present throughout the study area (Bovee and others, 2007).

Broadly, the aim for the SECI in the Delaware River Basin was to use the REFDSS as a platform to combine data collected by the USGS Leetown Science Center on freshwater mussel biofiltration, nutrient flux, storage, and retention with the economic valuation data collected by the USGS Fort Collins Science Center and develop a Freshwater Mussel Model (FMM). One feature of the REFDSS is its flexibility to incorporate different environmental attributes and habitat suitability criteria to allow managers to compare the effects of river management alternatives on different species. Both the freshwater mussel and economic valuation data collection efforts are described in the "Water Quality and Freshwater Mussels in the Delaware and Susquehanna River Basins-Lessons Learned" section. The long-term goal of this effort is to use our understanding of freshwater mussel filtration in the Upper Delaware River to guide conservation efforts in the Delaware River and restoration efforts in degraded systems where questions arise on the benefits of conserving and restoring freshwater mussel populations and their habitat. Development of a predictive model that links riverflow data to biofiltration and nutrient retention efficiencies of freshwater mussels provides policymakers with information on the benefits that freshwater mussels contribute to a healthy ecosystem, especially in areas with intensive agricultural development that may experience water quality issues.

The REFDSS platform enables comparison of instream flow scenarios and environmental attributes (for example, instream flow) on instream habitat for a variety of species including fish and mussels (see Maloney and others [2015] for background on model development). One feature of the REFDSS is its flexibility to incorporate different environmental attributes and habitat suitability criteria into the platform, which allows managers to compare the effects of river management alternatives on different species. Using the REFDSS platform as a starting point, USGS is developing a predictive model to link riverflow data to biofiltration and nutrient retention efficiencies of freshwater mussels.

The FMM relies on existing REFDSS flow release data developed from the Operational Analysis and Simulation System model. The model has a temporal resolution of 1 day and corresponds to both depth and velocity that converts outputs into a river discharge value for each of the 11 sites. The daily flow estimates are generated under three alternative flow release programs from the year 1928 through 2000. (Detailed information on REFDSS dynamics can be found in Maloney and others, 2015.) The FMM also utilizes datasets outside of the REFDSS tool to calculate mussel biomass by interpolating mussel density and scalar values of the average-sized mussels in an area. A static filtration rate applied in conjunction with river discharge and mussel biomass values estimate a final amount of water filtered for every 1-meter pixel that includes the site selected. The amount of filtered sediment determined by the FMM can be validated by checking if it matches SPAtially Referenced Regression On Watershed attributes (SPARROW) (https://www.usgs.gov/software/sparrow-modeling-program) data at the top and bottom of a selected site. The SPARROW model also calculates the sources of nitrogen and phosphorous (for example, fertilizer from corn, soy, and alfalfa; municipal point sources; atmospheric total inorganic nitrogen, manure, developed land, other fertilizers).

The ability to utilize data that exist within the REFDSS allows the FMM to complement the REFDSS outputs, which enables managers to evaluate the effects of competing flow release scenarios on mussel habitat suitability along the Upper Delaware River sites (Maloney and others, 2015). The attributes "Scenario," "Site," and "Date" were identified as important attributes that a user would define to acquire the correct Operational Analysis and Simulation System model spreadsheet from the REFDSS. A "Site" and "Date" selection specifies the values from a particular site and date to generate the river discharge raster. The users "Site" selection also applies to the "Mussel Biomass" and "SPARROW" layers. A static "Filtration Rate" multiplied by mussel biomass determines the amount of water that can be filtered over a given pixel; this amount of water can be divided by the river discharge value to calculate the percentage of total river discharge able to be filtered by mussels present for a given site. By comparing the FMM outputs to the SPARROW data, users can estimate the ecosystem service value of sediment and nutrient reduction downstream. The REFDSS data includes additional information on river velocities, substrates, and temperatures where mussels were observed; this data can be used to develop flow regime benchmarks to manage freshwater mussel populations. The FMM was developed in R (https://www.r-project.org), which allows for open source development of companion models that can strengthen the analysis as new data become available as well as allow for future versions of the REFDSS to be developed with existing R models/packages.

With much of the existing freshwater mussel research focusing on preserving and protecting imperiled populations, less attention has been paid to freshwater mussel ecology and the ability of freshwater mussels to filter water. The results from this analysis will allow for the exploration of the ecosystem services provided by freshwater mussels with regards to water quality, and compare these filtering efficiencies to SPARROW nutrient loading data, which will enable policymakers to consider other areas for freshwater mussel restoration (Ancona and others, 2018). 


\section{Artificial Intelligence for Ecosystem Services Modeling Platform—New Developments and an Application in the Desert Southwest}

The ARIES modeling platform is a networked software technology that aims to link ecosystem services data and models, thereby promoting their reuse and aiding in more rapid and accurate ecosystem service assessments. ARIES, which is available at http://aries.integratedmodelling.org/, has been in development since 2007 and in use since 2008 in various releases. ARIES development is motivated by a realization that overly simplified conceptual frameworks can lead to inaccurate policy decisions. Thus, ARIES strives to quantify the benefits that nature provides to society in a manner that accounts for dynamic complexity but is understandable, usable and reusable, and adaptable to conditions of varying data quality and availability. The platform employs integrated, multiple modeling techniques from look-up tables to deterministic equations, as well as probabilistic, process-based, machine learning, and agent-based models.

The SECI-specific effort used ARIES to develop models and analytic techniques to quantify and value ecosystem services within northern New Mexico's Santa Fe Fireshed under current and alternative landscape conditions. The effort combined stakeholder input, local knowledge and expertise, and the SECI's technical resources and capabilities to evaluate fire management strategies and landscape-level ecosystem service impacts. The original goal was to capitalize on the ARIES advanced modeling capabilities to look beyond the current short-term fire model period by exploring scenarios of landscape regeneration and postrecovery ecosystem services dynamics following prescribed fire treatments. These scenarios could then provide the foundation for an adaptive management framework developed by the Greater Santa Fe Fireshed Coalition.

ARIES has been used successfully in numerous recent applications (Bagstad and others, 2016, 2017; Willcock and others, 2018), but most of these efforts focused on the development of a model or suite of models for a single location. During the SECI-funded effort, ARIES underwent a systematic overhaul with a focus on the development of rapidly deployable, generalized Tier 1 models capable of serving as a default strategy for assessing ecosystem services when time or financial constraints preclude the development of more complex models (for example, agent-based) or the collection of locally derived data. Although general in nature, these models serve as a baseline for future customization depending on the context of application, the research and (or) management question(s) of relevance, and the availability of data with temporal currency and (or) spatial resolution that improve upon the national- to global-scale data that underpin the existing Tier 1 models. These models will also serve as the entry point to the ARIES Explorer, a web-based technology that allows non-technical users to select an area of interest, run models, and explore outputs without requiring advanced modeling or programming skills. The ARIES Explorer is scheduled for release in summer 2019 and will be freely accessible for non-commercial use.

Multiple discussions with stakeholders in the region around the Santa Fe Fireshed identified interest in modeling ecosystem services related to water quality and source water protection, as well as interest in other services such as support for cultural values, multiple forms of recreation, and timber and non-timber forest products. The original expectations for the SECI-funded effort were to identify a regional case study, engage with stakeholders, apply the ARIES tool to that case study, and disseminate results through a formal report. Although the updated, user-friendly interface was not yet available for SECI researchers, this effort did yield a successful implementation of models for carbon, flood regulation, pollination, recreation, and sediment regulation (Martinez-Lopez and others, 2019). In addition, a framework for conducting a spatial multiple criteria analysis (SMCA), based on the past work of Villa and others (2002), has also been tested for the region. The SMCA evaluates a set of observations (in this case, the supply of ecosystem services) from the context of stakeholder priorities (for example, ecosystem services, critical infrastructure). The resulting output provides data characterizing the concordance of the landscape with the desired condition(s) of stakeholders. The SMCA data can then be combined to identify landscape locations that provide critical ecosystem services based on stakeholder inputs. Given the existing relationship with stakeholder and management groups in the region, the SMCA could be deployed with minimal additional effort to seek common ground and foster collaboration to address landscape-level fire safety concerns.

Preliminary results of this effort demonstrating ARIES' machine learning, machine reasoning, and artificial intelligence functionality were presented to the Ecological Society of America in Portland, Oregon, on August 7, 2019 (Voigt, 2017). The Santa Fe case study was also highlighted as one of three demonstration projects describing the utility and application of the ARIES Tier 1 models across the globe (Martinez-Lopez and others, 2019).

\section{Ongoing Activities, Future Research Needs, and Organizational Structure}

The SECI features a wide portfolio of research activities that span diverse topical areas (for example, water quality, forest health, sagebrush services) and methods (for example, hedonic property premium method, contingent valuation, choice experiments, qualitative). The SECI was a designed to be a 3-year effort, running from fiscal years 2015 through the end of 2017. Some of the case studies and tool development projects had a full 3-years of research activities, but others started at the end of 
this 3-year cycle and are ongoing. For example, the case study described in the "Mixing National Water Quality Assessment Indicators with Economic House Pricing Models" section started in 2015 and was completed in 2018 (fig. 1). In contrast, the Chesapeake Bay Watershed: Stream and Floodplain Ecosystem Services research started in 2015 and, despite not receiving additional funds from the SECI, is expected to continue with additional analyses beyond 2019. Likewise, both the Ecosystem Services of Grasslands and Drylands and the Forest and Watershed Health in Northern New Mexico studies were initiated in 2017 and are anticipated to continue beyond 2019.

The need for this type of information is not expected to diminish, and every project could be expanded. The logical next step is the development of a technical advisory committee consisting of bureau partners to strategically target understudied ecosystem services or priority areas. One example within USGS of how direct lines of communication have been effective is the Wyoming Landscape Conservation Initiative which coordinates science needs directly with local governments and partnering Federal agencies in Wyoming (Bowen and others, 2018). The direct lines of communication established under the initiative have increased the effectiveness of both USGS science and identification of on-the-ground decision-making needs for USGS partners in southwestern Wyoming. Another way to improve communication and coordination of research needs is through an operational community of practice on ecosystem services that links agency experts.

Expanding on SECI activities, a future research priority could be to improve the integration of NAWQA data with economic valuation data. Collaborating closely with the NAWQA program to design a survey of local residents to closely tailor the survey attributes to the types of water quality indicators collected in the field is needed. This would help guide the economic data collection effort and would help guide which indicators might be most socially relevant for NAWQA researchers. Another future research opportunity with NAWQA could be to combine existing valuation data in the USGS Benefit Transfer Toolkit (for example, salmon valuation database) with other socially relevant water quality indicators (for example, salmon presenceabsence data) in other regions of the United States. However, questions remain about how to connect presence-absence data to either salmon population estimates or to catch rates, either of which would be needed to estimate an economic value.

There are many questions regarding ecosystem services for both the Delaware and Susquehanna River Basins. The effect of abandoned coal mining operations on water quality is a critical research question for the Susquehanna River Basin. In fact, stakeholder communication during SECI research activities indicated that acid mine drainage from abandoned mines may be a larger issue than nutrient and sediment loading on instream ecological health and human uses at the localized level. For the Delaware River Basin, issues remain surrounding competing uses for native aquatic species and game fisheries habitat.

In addition to ongoing SECI research activities, there are several notable areas where future ecosystem services research is needed to better inform Federal decision making. A key topic that remains understudied is the consideration of Tribal preferences for ecosystem services outcomes, for which economic valuation approaches have limitations (Winthrop, 2014). In the CES case study, qualitative methods are used to identify CES knowledge products (that is, sources of knowledge about the cultural importance of the natural World), including traditional and local knowledge and pathways for the incorporation of the knowledge in Federal decision making (see the "Cultural Ecosystem Services" section). Future research could leverage the generated typology and framework from the CES case study to guide quantitative methods such as a multicriteria decision analysis (Maguire, 2014) or stated preference choice experiments to estimate economic values for culturally sensitive ecosystem services (see the "Economic Valuation Methods" section for more information on choice experiments). Similar research is ongoing at the USGS Grand Canyon Monitoring Research Center in support of the Bureau of Reclamation Adaptive Management Program that studies Tribal preferences for Colorado River water flows released from the Glen Canyon Dam.

There is also room to coordinate PPGIS research (see the "Energy Exploration and Development in the Desert Southwest" section) with economic valuation methods. USGS researchers with the Geosciences and Environmental Change Science Center have developed tools, such as the Social Values for Ecosystem Services, that offer promise in this area (see Bagstad and others [2016] as an example application). In fact, a recent review by Brown and Fagerholm (2015) concludes that, although there is promise in applying PPGIS mapping methods for ecosystem services, a formalized, consistent framework is still needed.

Another promising and emerging area of ecosystem services research in USGS is an initiative to develop natural capital accounting assessments for the United States. Project information for the "Accounting for U.S. Ecosystem Services at National and Subnational Scales" working group is available at https://powellcenter.usgs.gov/view-project/57741607e4b07657d1a9910c. This research on natural capital accounting scales up localized ecosystem services assessments, such as those demonstrated by SECI case studies, to the national level and pairs ecosystem service data with the nation's economic accounts (Boyd and others, 2018). An exciting feature of natural capital accounting is that it tracks changes in the costs and benefits of ecosystem services and directly ties those changes to different sectors of the economy.

Finally, with respect to economic valuation tools, the USGS is well equipped to expand the collection of data, models, and best-practice guidance in the USGS Benefit Transfer Toolkit. For example, the USGS Benefit Transfer Toolkit includes recreation valuation data current as of 2014 but could be expanded to include more recent observations. For example, the Larson and Lew (2001) Beneficial Use Values Database is a valuation database that has not been updated in years. Regular updates to the USGS Benefit Transfer Toolkit databases are critical to ensure that USGS partners have access to the latest economic valuation data. Other summary databases can also be added to the USGS Benefit Transfer Toolkit, including those that pertain to drinking 
water elasticities of demand, the value of groundwater quality, and the value of instream flows. Additional preprogrammed meta-analyses can be added, including information on the value of open space (Kroger, 2008), river restoration (Bergstrom and Loomis, 2017), and wetlands (Woodward and Wui, 2001; Brander and others, 2006). The USGS Benefit Transfer Toolkit would also greatly benefit from field testing of the web-application interface with partners. Huber and Richardson (2016) aimed at testing the USGS Benefit Transfer Toolkit with BLM field offices for use in projects and plans but the effort was relatively limited in scope, focused primarily on outdoor recreational uses, and ultimately was qualitative due to data limitations. Lastly, developing an in-person training on how to use the USGS Benefit Transfer Toolkit in the field for both field-level staff and socioeconomics experts within the partnering bureaus would be beneficial.

\section{References Cited}

Ancona, Z.H., Semmens, D.J., Bagstad, K.J., Huber, C., Galbraith, H.S., and Spooner, D.E., 2018, Leveraging existing data in the Riverine Environmental Flow Decision Support System (REFDSS) to estimate sediment retention services provided by freshwater mussels in the Upper Delaware River Basin, in ACES-A Community on Ecosystem Services 2018 Conference, Washington, D.C., Dec 3-6, 2018, Abstracts: Gainesville, Fla., University of Florida, Institute of Food and Agricultural Sciences, p. 15.

Arts, B., Behagel, J., van Bommel, S., de Konig, J., and Turnhout, E., 2013, Prelude to practice—Introducing a practice based approach to forest and nature governance, in Arts, B., Behagel, J., van Bommel, S., de Konig, J., Turnhout, E., eds., Forest and nature governance-A practice based approach: Dordrecht, Holland, Springer, p. 3-21.

Bagstad, K.J., Reed, J.M., Semmens, D.J., Sherrouse, B. C., and Troy, A., 2016, Linking biophysical models and public preferences for ecosystem service assessments - A case study for the Southern Rocky Mountains: Regional Environmental Change, v. 16 no. 7 , p. $2005-2018$.

Bagstad, K.J., Semmens, D.J., Ancona, Z.H., and Sherrouse, B.C., 2017, Evaluating alternative methods for biophysical and cultural ecosystem services hotspot mapping in natural resource planning: Landscape Ecology, v. 32, no. 1, p. 77-97.

Banzhaf, H.S., 2010, Consumer surplus with apology-A historical perspective on nonmarket valuation and recreation demand: Annual Review of Resource Economics, v. 2, p. 183-207.

Bergstrom, J.C., and Loomis, J.B., 2017, Economic valuation of river restoration-An analysis of the valuation literature and its uses in decision-making: Water Resources and Economics, v. 17, p. 9-19.

Bockstael, N.E., Freeman, A.M., Kopp, R.J., Portney, P.R., and Smith, V.K., 2000, On measuring economic values for nature: Environmental Science \& Technology, v. 34 no. 8, p. 1384-1389.

Bovee, K.D., Waddle, T.J., Bartholow, J., and Burris, L., 2007, A decision support framework for water management in the Upper Delaware River: U.S. Geological Survey Open-File Report 2007-1172, 122 p., accessed August 13, 2019, at https://doi.org/10.3133/ofr20071172.

Bowen, Z.H., Aikens, E., Aldridge, C.L., Anderson, P.J., Assal, T.J., Chalfoun, A.D., Chong, G.W., Eddy-Miller, C.A., Garman, S.L., Germaine, S.S., Homer, C.G., Johnston, A., Kauffman, M.J., Manier, D.J., Melcher, C.P., Miller, K.A., Walters, A.W., Wheeler, J.D., Wieferich, D., Wilson, A.B., Wyckoff, T.B., and Zeigenfuss, L.C., 2018, U.S. Geological Survey science for the Wyoming Landscape Conservation Initiative-2016 annual report: U.S. Geological Survey Open-File Report 2018-1048, 49 p., accessed August 13, 2019, at https://doi.org/10.3133/ofr20181048.

Boyd, J., and Banzhaf, S., 2007, What are ecosystem services? The need for standardized environmental accounting units: Ecological Economics, v. 63, no. 2-3, p. 616-626.

Boyd, J.W., Bagstad, K.J., Ingram, J.C., Shapiro, C.D., Adkins, J.E., Casey, C.F., Duke, C.S., Glynn, P.D., Goldman, E., Grasso, M., Hass, J.L., Johnson, J.A., Lange, G., Matuszak, J., Miller, A., Oleson, K.L.L., Posner, S.M., Rhodes, C., Soulard, F., Vardon, M., Villa, F., Voigt, B., and Wentland, S., 2018, The natural capital accounting opportunity-Let's really do the numbers: BioScience, v. 68, no. 12, p. 940-943.

Boyle, K.J., 2017, Contingent valuation in practice, chap. 4 of Champ, P.A., Boyle, K.J., and Brown, T.C., eds., A primer on nonmarket valuation (2d ed.): The Netherlands, Springer, p. 83-131. 
Brander, L.M., Florax, R.J.G.M., and Vermaat, J.E., 2006, The empirics of wetland valuation-A comprehensive summary and a meta-analysis of the literature: Environmental and Resource Economics, v. 33, no. 2, p. 223-250.

Brown, G., and Fagerholm, N., 2015, Empirical PPGIS/PGIS mapping of ecosystem services-A review and evaluation: Ecosystem Services, v. 13, p.119-133.

Brown, T.C., 2017, Substitution methods, chap. 9 of Champ, P.A., Boyle, K.J., and Brown, T.C., eds., A primer on nonmarket valuation (2d ed.): The Netherlands, Springer, p. 347-390.

Brown, T.C., Bergstrom, J.C., and Loomis, J.B., 2007, Defining, valuing, and providing ecosystem goods and services: Natural Resources Journal, v. 47, p. 329-376.

Champ, P.A., Boyle, K.J., and Brown, T.C., eds., 2017, A primer on nonmarket valuation ( $2 \mathrm{~d}$ ed.): The Netherlands, Springer, $504 \mathrm{p}$.

Charmaz, K., 2006, Constructing grounded theory-A practical guide through qualitative analysis: Los Angeles, Sage Publications Inc., 208 p.

Coase, R.H., 1960, The problem of social cost: The Journal of Law \& Economics, v. 3, p. 1-44.

Constanza, R., and Daly, H.E., 1992, Natural capital and sustainable development: Conservation Biology, v. 6, no. 1, p. 37-46.

Costanza, R., d'Arge, R., de Groot, R., Farber, S., Grasso, M., Hannon, B., Limburg, K., Naeem, S. O’Neill, R.V., Paruelo, J., Raskin, R.G., Sutton, P., and van den Belt, M., 1997, The value of the World's ecosystem services and natural capital: Nature, v. 387, p. $253-260$.

Daily, G.C., ed., 1997, Nature's services—Societal dependence on natural ecosystems: Washington, D.C., Island Press, 412 p.

Dalhuisen, J.M., Florax, R.J.G.M., de Groot, H.L.F.M., and Nijkamp, P., 2001, Price and income elasticities of residential water demand-Why empirical estimates differ: The Netherlands, Tinbergen Institute Discussion Paper No. 01-057/3, 42 p.

Davis, R.K., 1963, The value of outdoor recreation-An economic study of the Maine woods: Cambridge, Mass., Harvard University, unpublished Ph.D. dissertation, 304 p.

Ehrlich, P.R., and Ehrlich, A.H., 1981, Extinction-The causes and consequences of the disappearance of species: New York, Random House, 305 p.

Espey, M., Espey, J., and Shaw, W.D., 1997, Price elasticity of residential demand for water-A meta-analysis: Water Resources Research, v. 33, no. 6, p. 1369-1374.

Federal Inter-Agency River Basin Committee, Subcommittee on Benefits and Costs, 1950, Proposed practices for economic analysis of river basin projects: Washington, D.C., U.S. Government Printing Office, 94 p.

Freeman, A.M., III, 2003, The measurement of environmental and resource values—Theory and methods (2d ed.): Washington, D.C., Resources for the Future, $491 \mathrm{p}$.

Freeman, A.M., III, Haveman, R.H., and Kneese, A.V., 1973, The economics of environmental policy: New York, John Wiley, $184 \mathrm{p}$.

Gibbons, D.C., 1986, The economic value of water: Washington, D.C., Resources for the Future, 184 p.

Habb, T.C., and McConnell, K.E., 2002, Valuing environmental and natural resources-The econometrics of non-market valuation: Northampton, Mass., Edward Eldar Publishing, 326 p.

Haefele, M., Loomis, J., Meldrum, J., and Huber, C., 2018, Economic value of ecosystem services supported by dryland and grassland environments, [poster presented at] Great Plains Grassland Summit, Denver, Colo., April 10-11, 2018: U.S. Geological Survey, 1 sheet.

Hanemann, W.H., 2005, The economic conception of water, chap. 4 of Rogers, P.P., Llamas, M.R., and Martinez-Cortina, L., eds., Water crisis - Myth or reality?: London, CRC Press, p. 61-91.

Holmes, T.P., Adamowicz, W.L., and Carlsson, F., 2017, Choice experiments, chap. 5 of Champ, P.A., Boyle, K.J., and Brown, T.C., eds., A primer on nonmarket valuation (2d ed.): The Netherlands, Springer, p. 133-186. 
Homer, C., Dewitz, J., Yang, L., Jin, S., Danielson, P., Xian, G., Coulston, J., Herold, N., Wickham, J., and Megown, K., 2015, Completion of the 2011 National Land Cover Database for the conterminous United States-Representing a decade of land cover change information: Photogrammetric Engineering \& Remote Sensing, v. 81, no. 5, p. 345-354.

Hopkins, K.G., Lamont, S., Claggett, P.R., Noe, G.B., Gellis, A.C., Lawrence, C.B., Metes, M.J., Strager, M.P., and Strager, J.M., 2018a, Stream Channel and Floodplain Metric Toolbox: U.S. Geological Survey data release, accessed August 13, 2019, at https://doi.org/10.5066/F7X34WF4.

Hopkins, K.G., Metes, M.J., Noe, G.B., and Claggett, P.R., 2018b, Difficult Run Floodplain Sediment and Nutrient Retention Ecosystem Service Datasets, Fairfax County, Virginia: U.S. Geological Survey data release, accessed August 13, 2019, at https://doi.org/10.5066/F7K936HB.

Hopkins, K.G., Noe, G.B., Franco, F., Pindilli, E.J., Gordon, S., Metes, M.J., Claggett, P.R., Gellis, A.C., Hupp, C.R., and Hogan. D.M., 2018c, A method to quantify and value floodplain sediment and nutrient retention ecosystem services: Journal of Environmental Management, v. 220, p. 65-76. [Also available at https://doi.org/10.1016/j.jenvman.2018.05.013.]

Hotelling, H., 1931, The economics of exhaustible resources: Journal of Political Economy, v. 39, no. 2, p. 137-175.

Huber, C., Meldrum, J., and Richardson, L., 2018, Improving confidence by embracing uncertainty-A meta-analysis of U.S. hunting values for benefit transfer: Ecosystem Services, v. 33, p. 225-236.

Huber, C., and Richardson, L., 2016, Facilitating the inclusion of nonmarket values in Bureau of Land Management planning and project assessments-Final report: U.S. Geological Survey Open-File Report 2016-1178, 79 p., accessed January 18, 2019, at https://doi.org/10.3133/ofr20161178.

Johnston, R.J., Besedin E.Y., and Stapler R., 2017, Enhanced geospatial validity for meta-analysis and environmental benefit transfer-An application to water quality improvements: Environmental and Resource Economics, v. 68, no. 2, p. 343-375.

Johnston, R.J., Rolfe, J., Rosenberger, R., Brouwer, R., eds., 2015, Benefit transfer of environmental and resource values-A guide for researchers and practitioners: New York, Springer, $582 \mathrm{p}$.

Johnston, R.J., and Thomassin, P.J., 2010, Willingness to pay for water quality improvements in the United States and CanadaConsidering possibilities for international meta-analysis and benefit transfer: Agricultural and Resource Economics Review, v. 39 , no. 1 , p. $114-131$.

Kauffman, G.J., 2016, Economic value of nature and ecosystems in the Delaware River Basin: Journal of Contemporary Water Research \& Education, v. 158, no. 1, p. 98-119.

Knetsch, J.L., and Davis, R.K., 1966, Comparisons of methods for recreation evaluation, in Kneese, A.V., and Smith, S.C., eds., Water research: Baltimore, Md., Johns Hopkins Press, p. 125-142.

Kroeger, T., 2008, Open space property value premium analysis: Washington, D.C., National Council for Science and the Environment, $80 \mathrm{p}$.

Krutilla, J.V., 1967, Conservation reconsidered: The American Economic Review, v. 57, no. 4, p. 777-786.

Landers, D.H., and Nahlik, A.M., 2013, Final ecosystem goods and services classification system (FEGS-CS): Corvallis, Oreg., U.S. Environmental Protection Agency, EPA/600/R-13/ORD-004914, 108 p.

Larson, D.M., and Lew, D.K., 2001, Beneficial Use Values Database: Davis, Calif., University of California, Davis, Department of Agricultural and Resource Economics, accessed August 13, 2019, at http://buvd.ucdavis.edu/.

Lawrence, C.B., Pindilli, E.J., and Hogan, D.M., 2019, Valuation of the flood attenuation ecosystem service in Difficult Run, VA, USA: Journal of Environmental Management, v. 231, p. 1056-1064. [Also available at https://doi.org/10.1016/j.jenvman.2018.10.023.]

Maguire, L.A., 2014, Multicriteria evaluation for ecosystem services-A brief primer: Durham, N.C., Duke University, Ecosystem Services Working Group, 25 p.

Maloney, K.O., Talbert, C.B., Cole, J.C., Galbraith, H.S., Blakeslee, C.J., Hanson, L., and Holmquist-Johnson, C.L., 2015, An integrated Riverine Environmental Flow Decision Support System (REFDSS) to evaluate the ecological effects of alternative flow scenarios on river ecosystems: Fundamental and Applied Limnology, v. 186, no. 1-2, p. 171-192. 
Martínez-López, J., Bagstad, K.J., Balbi, S., Magrach, A., Voigt, B., Athanasiadis, I., Pascual, M., Willcock, S., and Villa, F., 2019, Towards globally customizable ecosystem service models: Science of the Total Environment, v. 650, no. 2, p. $2325-2336$.

Meldrum, J., and Huber, C., 2019, An economic perspective on the relationship between wilderness and water resources: Natural Areas Journal, v. 39, no. 1, p. 33-45.

Millennium Ecosystem Assessment, 2005, Ecosystems and human well-being—Synthesis: Washington, D.C., Island Press, 137 p.

National Park Service, 1949, The economics of public recreation-An economic study of the monetary evaluation of recreation in the national parks: Washington, D.C., National Park Service, Land and Recreational Planning Division, 64 p.

Office of Management and Budget, Council on Environmental Quality, and Office of Science and Technology Policy, 2015, Memorandum for Executive Departments and Agencies M-16-01- Incorporating ecosystem services into Federal decision making: Executive Office of the President, 5 p. [Also available at https://www.whitehouse.gov/sites/whitehouse.gov/files/ omb/memoranda/2016/m-16-01.pdf.]

Olander, L., Bagstad, K., Characklis, G.W., Comer, P., Effron, M., Gunn, J., Holmes, T., Johnston, R., Kagan, J., Lehman, W., Lonsdorf, E., Loomis, J., McPhearson, T., Neale, A., Patterson, L., Richardson, L., Ricketts, T., Ross, M., Saah, D., Sifleet, S., Stockmann, K., Urban, D., Wainger, L., Winthrop, R., and Yoskowitz, D., 2017, Data and modeling infrastructure for national integration of ecosystem services into decision making - Expert summaries: Durham, N.C., Duke University, National Ecosystem Services Partnership Working Paper 16-02, $106 \mathrm{p}$.

Oregon State University, 2016, Recreation Use Values Database: Corvallis, Oreg., Oregon State University, College of Forestry, accessed August 29, 2017, at http://recvaluation.forestry.oregonstate.edu/.

Perrings, C., Folke, C., and Mäler, K.G., 1992, The ecology and economics of biodiversity loss-The research agenda: Ambio, v. 21 , no. 3, p. 201-211.

President's Council of Advisors on Science and Technology, 2011, Report to the President, Sustaining environmental capitalProtecting society and the economy: Washington, D.C., Executive Office of the President, 125 p., accessed July 2, 2019, at https://obamawhitehouse.archives.gov/sites/default/files/microsites/ostp/pcast_sustaining_environmental_capital_report.pdf.

Richardson, L., and Loomis, J., 2009, The total economic value of threatened, endangered and rare species-An updated metaanalysis: Ecological Economics, v. 68, p. 1535-1548.

Richardson, L., Loomis, J., Kroeger, T., and Casey, F., 2015, The role of benefit transfer in ecosystem service valuation: Ecological Economics, v. 115, p. 51-58.

Richardson, L., and Peacock, B., 2018, National parks in developed counties: Oxford, England, Oxford University Press, Oxford Research Encyclopedia of Environmental Science, 48 p. [Also available at https://oxfordre.com/environmentalscience/ view/10.1093/acrefore/9780199389414.001.0001/acrefore-9780199389414-e-436.]

Rosenberger, R.S., and Loomis, J.B., 2017, Benefit transfer, chap. 11 of Champ, P.A., Boyle, K.J., and Brown, T.C., eds., A primer on nonmarket valuation ( $2 \mathrm{~d}$ ed.): The Netherlands, Springer, p. 431-462.

Rosenberger, R.S., White, E.M., Kline, J.D., and Cvitanovich, C., 2017, Recreation economic values for estimating outdoor recreation economic benefits from the National Forest System: Portland, Oreg., U.S. Department of Agriculture, Forest Service, Pacific Northwest Research Station, General Technical Report PNW-GTR-957, 39 p.

Scheierling, S.M., Loomis, J.B., and Young, R.A., 2006, Irrigation water demand-A meta-analysis of price elasticities: Water Resources Research, v. 42, no. 1, W01411, 9 p.

Segerson, K., 2017, Valuing environmental goods and services-An economic perspective, chap. 1 of Champ, P.A., Boyle, K.J., Brown, T.C., eds., A primer on nonmarket valuation ( $2 \mathrm{~d}$ ed.): The Netherlands, Springer, p. 1-25.

Shapiro, C., 2015, Ecosystem services science and practice-Policy, opportunities, and new directions, in Van Weelden M., De Groot R., and Konovska, I., 2015, Eighth International Ecosystem Services Partnership (ESP) Conference Program Booklet, November 2015, Stellenbosch, South Africa: Wageningen, The Netherlands, Foundation for Sustainable Development, p. 36. [Also available at https://drive.google.com/drive/folders/0BzhWq2qX30qQTk03NE1fLUNMdmc.] 
Taylor, L.O., 2017, Hedonics, chap. 7 of Champ, P.A., Boyle, K.J., Brown, T.C., eds., A primer on nonmarket valuation (2d ed.): The Netherlands, Springer, p. 235-292.

Tengö, M., Brondizio, E.S., Elmqvist, T., Malmer, P., and Spierenberg, M., 2014, Connecting diverse knowledge systems for enhanced ecosystem governance-The multiple evidence base approach: Ambio, v. 43, p. 579-591.

Toman, M., 1998, Special section-Forum on valuation of ecosystem services. Why not to calculate the value of the World's ecosystem services and natural capital: Ecological Economics, v. 25, no. 1, p. 57-60.

Trice, A.H., and Wood, S.E., 1958, Measurement of recreation benefits: Land Economics, v. 34, no. 3, p. $195-207$.

U.S. Environmental Protection Agency, 2013, The importance of water to the U.S. economy-Synthesis report: Washington, D.C., U.S. Environmental Protection Agency, Office of Water, 29 p.

U.S. Geological Survey [USGS], 2014, The National Map-Governmental units/boundaries: U.S. Geological Survey web page, accessed October 5, 2017, at https://nationalmap.gov/small_scale/atlasftp.html\#fedlanp.

U.S. Geological Survey [USGS], 2017, Benefit Transfer Toolkit: U.S. Geological Survey web page, accessed August 14, 2019, at https://my.usgs.gov/benefit-transfer/.

U.S. Geological Survey [USGS], 2018, U.S. Department of the Interior Natural Value Resource Center: U.S. Geological Survey web page, accessed August 14, 2019, at https://doi.sciencebase.gov/nvrc/\#/.

Villa, F., Tunesi, L., and Agardy, T., 2002, Zoning marine protected areas through spatial multiple-criteria analysis-The case of the Asinara Island National Marine Reserve of Italy: Conservation Biology, v.16, no. 2, p. 515-526.

Voigt, B., 2017, Econometric and agent-based modeling approaches to modeling freshwater ecosystem services, [presented at] 2017 Annual Meeting of the Ecological Society of America, Portland, Oreg., Aug 6-11, 2017, Symposia: Washington, D.C., Ecological Society of America. [Also available at https://eco.confex.com/eco/2017/webprogram/Paper62243.html.]

Weber, M.A., 2015, Navigating benefit transfer for salmon improvements in the Western US: Frontiers in Marine Science, v. 2 , p. $1-17$.

Westman, W.E., 1977, How much are nature's services worth?: Science, v. 197, no. 4307, p. 960-964.

Willcock, S., Martínez-López, J., Hooftman, D.A.P., Bagstad, K.J., Balbi, S., Marzo, A., Prato, C., Sciandrello, S., Signorello, G., Voigt, B., Villa, F., Bullock, J.M., and Athanasiadis, I.N., 2018, Machine learning for ecosystem services: Ecosystem Services, v. 33, pt. B., p. 165-174.

Winthrop, R.H., 2014, The strange case of cultural services_Limits of the ecosystem services paradigm: Ecological Economics, v. 108 , p. 208-214.

Woodward, R.T., and Wui, Y.S., 2001, The economic value of wetland services-A meta-analysis: Ecological Economics, v. 37, no. 2, p. 257-270.

Young, R.A., and Loomis, J.B., 2014, Determining the economic value of water-Concepts and methods (2d ed.): New York, RFF Press, 358 p.

Publishing support provided by the Science Publishing Network,

Denver Publishing Service Center

For more information concerning the research in this report, contact the Center Director, USGS Fort Collins Science Center

2150 Centre Ave., Bldg. C

Fort Collins, CO 80526-8118

(970) 226-9398

Or visit the Fort Collins Science Center website at

https://www.usgs.gov/centers/fort 


\section{Appendix 1. Sustaining Environmental Capital Initiative Research Products}

Table 1.1. List of Sustaining Environmental Capital Initiative research products.

\begin{tabular}{|c|c|c|c|}
\hline Author(s) & $\begin{array}{l}\text { Title of } \\
\text { product }\end{array}$ & $\begin{array}{l}\text { Type of } \\
\text { product }\end{array}$ & $\begin{array}{l}\text { Presentation/availability } \\
\text { information }\end{array}$ \\
\hline $\begin{array}{l}\text { Z.H. Ancona, D.J. Semmens, } \\
\text { K.J. Bagstad, C. Huber, } \\
\text { H.S. Galbraith, and D.E. } \\
\text { Spooner }\end{array}$ & $\begin{array}{l}\text { "Leveraging Existing Data in the Riverine En- } \\
\text { vironmental Flow Decision Support System } \\
\text { (REFDSS) to Estimate Sediment Retention } \\
\text { Services Provided by Freshwater Mussels in the } \\
\text { Upper Delaware River Basin" }\end{array}$ & $\begin{array}{l}\text { Conference } \\
\text { presentation }\end{array}$ & $\begin{array}{l}\text { ACES-A Community on Ecosystem } \\
\text { Services } 2018 \text { Conference, Wash- } \\
\text { ington, D.C., December 3-6, } 2018\end{array}$ \\
\hline $\begin{array}{l}\text { D. Hogan, E. Pindilli, K. } \\
\text { Hopkins, F. Franco, and } \\
\text { S. Gordon }\end{array}$ & $\begin{array}{l}\text { "Chesapeake Bay Watershed-Stream and Flood- } \\
\text { plain Ecosystem Services" }\end{array}$ & $\begin{array}{l}\text { Conference } \\
\text { presentation }\end{array}$ & $\begin{array}{l}\text { ACES_A Community on Ecosystem } \\
\text { Services } 2016 \text { Conference, Jackson- } \\
\text { ville, Florida, December 5-9, } 2016\end{array}$ \\
\hline $\begin{array}{l}\text { D. Hogan, E. Pindilli, K.G. } \\
\text { Hopkins, C. Lawrence, F. } \\
\text { Franco, S. Gordon, and } \\
\text { G. Noe }\end{array}$ & $\begin{array}{l}\text { "Stream and Floodplain Ecosystem Services in the } \\
\text { Chesapeake Bay Watershed" }\end{array}$ & $\begin{array}{l}\text { Conference } \\
\text { presentation }\end{array}$ & $\begin{array}{l}\text { Ecosystem Services_-From Concept to } \\
\text { Policy Symposia, Washington, D.C., } \\
\text { May } 2017\end{array}$ \\
\hline $\begin{array}{l}\text { T. Holmes, J. Meldrum, R. } \\
\text { Schuster, C. Huber, B. } \\
\text { Quay, and B. Voigt }\end{array}$ & $\begin{array}{l}\text { "Estimating Ecosystem Service Benefits from a } \\
\text { Western U.S. Wilderness Area" }\end{array}$ & $\begin{array}{l}\text { Conference } \\
\text { presentation }\end{array}$ & $\begin{array}{l}\text { ACES_A Community on Ecosystem } \\
\text { Services } 2016 \text { Conference, Jackson- } \\
\text { ville, Florida, December 5-9, } 2016\end{array}$ \\
\hline $\begin{array}{l}\text { K. Hopkins, D. Hogan, } \\
\text { E. Pindilli, G. Noe, F. } \\
\text { Franco, and S. Gordon }\end{array}$ & $\begin{array}{l}\text { "Quantifying and Valuing Floodplain Nutrient and } \\
\text { Sediment Retention" }\end{array}$ & $\begin{array}{l}\text { Conference } \\
\text { presentation }\end{array}$ & $\begin{array}{l}\text { ACES_A Community on Ecosystem } \\
\text { Services } 2016 \text { Conference, Jackson- } \\
\text { ville, Florida, December 5-9, } 2016\end{array}$ \\
\hline $\begin{array}{l}\text { K.G. Hopkins, S. Lamont, } \\
\text { P.R. Claggett, G.B. Noe, } \\
\text { A.C. Gellis, C.B. Law- } \\
\text { rence, M.J. Metes, M.P. } \\
\text { Strager, and J.M. Strager }\end{array}$ & "Stream Channel and Floodplain Metric Toolbox" & $\begin{array}{l}\text { USGS data } \\
\text { release }\end{array}$ & $\begin{array}{l}\text { U.S. Geological Survey data release, } \\
\text { 2018, https://doi.org/10.5066/ } \\
\text { F7X34WF4 }\end{array}$ \\
\hline $\begin{array}{l}\text { K.G. Hopkins, G. Noe, S. } \\
\text { Lamont, P. Claggett, D. } \\
\text { Hogan, and E. Pindilli }\end{array}$ & "Quantifying Floodplain Ecosystem Services" & $\begin{array}{l}\text { Conference } \\
\text { presentation }\end{array}$ & $\begin{array}{l}\text { Annual Freshwater Science Meeting, } \\
\text { Detroit, Michigan, } 2018\end{array}$ \\
\hline $\begin{array}{l}\text { K.G. Hopkins, G. Noe, S. } \\
\text { Lamont, P. Claggett, D. } \\
\text { Hogan, and E. Pindilli }\end{array}$ & "Adding Up Floodplain Benefits" & $\begin{array}{l}\text { Conference } \\
\text { presentation }\end{array}$ & $\begin{array}{l}\text { Ecological Society of America Annual } \\
\text { Meeting, New Orleans, Louisiana, } \\
\text { August } 2018\end{array}$ \\
\hline $\begin{array}{l}\text { K.G. Hopkins, G. Noe, S. } \\
\text { Lamont, P. Claggett, D. } \\
\text { Hogan, and E. Pindilli }\end{array}$ & "Quantifying Floodplain Ecosystem Services" & $\begin{array}{l}\text { Conference } \\
\text { presentation }\end{array}$ & $\begin{array}{l}\text { Sixth Interagency Conference on } \\
\text { Research in the Watersheds, } \\
\text { (2018), Shepherdstown, West } \\
\text { Virginia, July } 2018\end{array}$ \\
\hline
\end{tabular}


Table 1.1. List of Sustaining Environmental Capital Initiative research products.-Continued

\begin{tabular}{|c|c|c|c|}
\hline Author(s) & $\begin{array}{l}\text { Title of } \\
\text { product }\end{array}$ & $\begin{array}{l}\text { Type of } \\
\text { product }\end{array}$ & $\begin{array}{l}\text { Presentation/availability } \\
\text { information }\end{array}$ \\
\hline $\begin{array}{l}\text { C. Huber, D. Carlisle, and } \\
\text { B. Quay }\end{array}$ & $\begin{array}{l}\text { "Leveraging the USGS National Water-Quality } \\
\text { Assessment Program Data in Hedonic Property } \\
\text { Models" }\end{array}$ & $\begin{array}{l}\text { Conference } \\
\text { presentation }\end{array}$ & $\begin{array}{l}\text { ACES_A Community on Ecosystem } \\
\text { Services } 2016 \text { Conference, Jackson- } \\
\text { ville, Florida, December 5-9, } 2016\end{array}$ \\
\hline C. Huber & "Benefit Transfer Toolkit" & $\begin{array}{l}\text { Workshop pre- } \\
\text { sentation }\end{array}$ & $\begin{array}{l}\text { DOI Economics Workshop, Washing- } \\
\text { ton, D.C., April 5-7, } 2017\end{array}$ \\
\hline C. Huber, and J. Meldrum & $\begin{array}{l}\text { "Economic Benefits from Drylands \& Sagebrush } \\
\text { Ecosystems" }\end{array}$ & $\begin{array}{l}\text { Workshop pre- } \\
\text { sentation }\end{array}$ & $\begin{array}{l}\text { DOI Economics Workshop, Washing- } \\
\text { ton, D.C., September 26-27, } 2018\end{array}$ \\
\hline $\begin{array}{l}\text { T. Kern, G. Montgomery, } \\
\text { J. Long, M. Eberhardt- } \\
\text { Frank, and T. Miller }\end{array}$ & $\begin{array}{l}\text { "Designing and Implementing an Ecosystems Ser- } \\
\text { vices Data Integration and Distribution Frame- } \\
\text { work" }\end{array}$ & $\begin{array}{l}\text { Conference } \\
\text { presentation }\end{array}$ & $\begin{array}{l}\text { ACES_A Community on Ecosystem } \\
\text { Services } 2016 \text { Conference, Jackson- } \\
\text { ville, Florida, December 5-9, } 2016\end{array}$ \\
\hline $\begin{array}{l}\text { C. Lawrence, E. Pindilli, and } \\
\text { D. Hogan }\end{array}$ & $\begin{array}{l}\text { "Valuation of the Flood Attenuation Ecosystem } \\
\text { Service in Difficult Run, VA, USA" }\end{array}$ & $\begin{array}{l}\text { Conference } \\
\text { presentation }\end{array}$ & $\begin{array}{l}\text { ACES-A Community on Ecosystem } \\
\text { Services } 2018 \text { Conference, Wash- } \\
\text { ington, D.C., December 3-6, } 2018\end{array}$ \\
\hline $\begin{array}{l}\text { C. Lawrence, E.J. Pindilli, } \\
\text { and D.M. Hogan }\end{array}$ & $\begin{array}{l}\text { "Valuation of the Flood Attenuation Ecosystem } \\
\text { Service in Difficult Run, VA, USA" }\end{array}$ & Journal article & $\begin{array}{l}\text { Journal of Environmental Manage- } \\
\text { ment, 2019, v. 231, p. 1056-1064 }\end{array}$ \\
\hline $\begin{array}{l}\text { J. Martínez-López, K.J. Bag- } \\
\text { stad, S. Balbi, A. Magrach, } \\
\text { B. Voigt, I. Athanasiadis, } \\
\text { M. Pascual, S. Willcock, } \\
\text { and F. Villa }\end{array}$ & $\begin{array}{l}\text { "Towards Globally Customizable Ecosystem Ser- } \\
\text { vice Models" }\end{array}$ & Journal article & $\begin{array}{l}\text { Science of the Total Environment, } \\
2019 \text {, v. } 650 \text {, no. } 2 \text {, p. } 2325-2336\end{array}$ \\
\hline J.R. Meldrum & "Economic Benefits of Stream Health" & $\begin{array}{l}\text { Workshop pre- } \\
\text { sentation }\end{array}$ & $\begin{array}{l}\text { DOI Economics Workshop, Washing- } \\
\text { ton, D.C., April 5-7, } 2017\end{array}$ \\
\hline J. Meldrum and C. Huber & $\begin{array}{l}\text { "An Economic Perspective on the Relationship } \\
\text { Between Wilderness and Water Resources" }\end{array}$ & Journal article & $\begin{array}{l}\text { Natural Areas Journal, 2019, v. } 39 \text {, } \\
\text { no. } 1 \text {, p. } 33-45\end{array}$ \\
\hline J. Meldrum and C. Huber & $\begin{array}{l}\text { "An Economic Perspective on the Relationship } \\
\text { Between Wilderness and Water Resources" }\end{array}$ & $\begin{array}{l}\text { Conference } \\
\text { presentation }\end{array}$ & $\begin{array}{l}\text { ACES-A Community on Ecosystem } \\
\text { Services } 2018 \text { Conference, Wash- } \\
\text { ington, D.C., December 3-6, } 2018\end{array}$ \\
\hline $\begin{array}{l}\text { J.R. Meldrum, B. Quay, C. } \\
\text { Huber, and D. Carlisle }\end{array}$ & $\begin{array}{l}\text { "Estimating Ecosystem Services Using the USGS's } \\
\text { National Water-Quality Assessment (NAWQA) } \\
\text { Data" }\end{array}$ & $\begin{array}{l}\text { Conference } \\
\text { presentation }\end{array}$ & $\begin{array}{l}\text { W3133 Annual Meeting-Benefits and } \\
\text { Costs of Natural Resources Policies } \\
\text { Affecting Ecosystem Services on } \\
\text { Public and Private Lands, Carlsbad, } \\
\text { California, February 22-24, } 2017\end{array}$ \\
\hline $\begin{array}{l}\text { E. Patterson, C. Huber, J.R. } \\
\text { Meldrum, R. Schuster, } \\
\text { M. Eberhardt-Frank, } \\
\text { T. Miller. T. Kern. G. }\end{array}$ & $\begin{array}{l}\text { "The Natural Value Resource Center-An Ecosys- } \\
\text { tem Services Data Integration and Distribution } \\
\text { Framework for DOI" }\end{array}$ & $\begin{array}{l}\text { Poster presen- } \\
\text { tation }\end{array}$ & $\begin{array}{l}\text { 23rd Annual Front Range Ecology } \\
\text { Symposium, Fort Collins, Colorado, } \\
\text { February 22-23, } 2017\end{array}$ \\
\hline
\end{tabular}
T. Miller, T. Kern, G. Montgomery, J. Long, and B. Quay 
Table 1.1. List of Sustaining Environmental Capital Initiative research products.-Continued

\begin{tabular}{|c|c|c|c|}
\hline Author(s) & $\begin{array}{l}\text { Title of } \\
\text { product }\end{array}$ & $\begin{array}{l}\text { Type of } \\
\text { product }\end{array}$ & $\begin{array}{l}\text { Presentation/availability } \\
\text { information }\end{array}$ \\
\hline D.E Spooner & $\begin{array}{l}\text { "Characterizing the Biophysical Component of } \\
\text { Ecosystem Services Along Gradients of Anthro- } \\
\text { pogenic Stressors" }\end{array}$ & $\begin{array}{l}\text { Classroom } \\
\text { presentation }\end{array}$ & $\begin{array}{l}\text { Sam Houston State University, De- } \\
\text { partment of Biological Sciences, } \\
\text { Huntsville, Texas, } 2016\end{array}$ \\
\hline $\begin{array}{l}\text { D. Spooner, C. Huber, J. } \\
\text { Loomis, H. Galbraith, C. } \\
\text { Talbert, M. Haefele, B. } \\
\text { Quay, and B. White }\end{array}$ & $\begin{array}{l}\text { "Linking Water Management and Natural Capital } \\
\text { Using an Ecosystem Services Framework" }\end{array}$ & $\begin{array}{l}\text { Conference } \\
\text { presentation }\end{array}$ & $\begin{array}{l}\text { ACES-A Community on Ecosystem } \\
\text { Services } 2016 \text { Conference, Jackson- } \\
\text { ville, Florida, December 5-9, } 2016\end{array}$ \\
\hline $\begin{array}{l}\text { B. St. John White, D.E. } \\
\text { Spooner, and H.S. Gal- } \\
\text { braith }\end{array}$ & $\begin{array}{l}\text { "Estimating Ecosystem Function and Services of } \\
\text { Native Mussels in the Delaware and Susque- } \\
\text { hanna Rivers" }\end{array}$ & $\begin{array}{l}\text { Workshop pre- } \\
\text { sentation }\end{array}$ & $\begin{array}{l}\text { Chesapeake Bay Freshwater Mussel } \\
\text { Work Group Meeting, Annapolis, } \\
\text { Maryland, January 31, } 2017\end{array}$ \\
\hline $\begin{array}{l}\text { B. St. John White, D.E. } \\
\text { Spooner, H.S. Galbraith, } \\
\text { C. Huber, and B. Quay }\end{array}$ & $\begin{array}{l}\text { "Instream Ecosystem Processes and Stream } \\
\text { Health-Assessing Ecosystem Services Provided } \\
\text { by Native Freshwater Mussels in the Delaware } \\
\text { and Susquehanna Rivers" }\end{array}$ & $\begin{array}{l}\text { Conference } \\
\text { presentation }\end{array}$ & $\begin{array}{l}\text { 11th Annual Susquehanna River Sym- } \\
\text { posium, Lewisburg, Pennsylvania, } \\
\text { November 11-12, } 2016\end{array}$ \\
\hline U.S. Geological Survey & "Benefit Transfer Toolkit" & Website & $\begin{array}{l}\text { U.S. Geological Survey website, } \\
\text { https://my.usgs.gov/benefit-transfer/ }\end{array}$ \\
\hline U.S. Geological Survey & $\begin{array}{l}\text { "U.S. Department of the Interior Natural Value } \\
\text { Resource Center" }\end{array}$ & Website & $\begin{array}{l}\text { U.S. Geological Survey website, } \\
\text { https://doi.sciencebase.gov/nvrc/\#/ }\end{array}$ \\
\hline B. Voigt & $\begin{array}{l}\text { "Econometric and Agent Based Modeling Ap- } \\
\text { proaches to Modeling Freshwater Ecosystem } \\
\text { Services" }\end{array}$ & $\begin{array}{l}\text { Conference } \\
\text { presentation }\end{array}$ & $\begin{array}{l}\text { Annual Meeting of the Ecological So- } \\
\text { ciety of America, Portland, Oregon, } \\
\text { August Aug 6-11, } 2017\end{array}$ \\
\hline
\end{tabular}




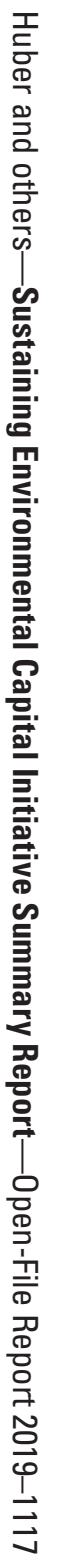

